\title{
Om idræt, sociologi og historie i oplevelsessamfundet
}

Af Søren Nagbøl

\section{Oplevelsessamfundets dilemma}

Det idrætsbillede, der tegner sig nu om dage, er et vigtigt udtryk for de kulturelle livsmønstre, som gør sig gældende i oplevelsessamfundet. Begrebet stammer fra Gerhard Schulzes bog fra 1993 Die Erlebnisgesellschaft. Kultursoziologie der Gegenwart. ${ }^{1}$ Den er resultat af en stor undersøgelse, der viser, at i de sidste 20-30 år har det vesttyske samfund været i en rivende udvikling, som har medført store forandringer. Det er radikale strukturændringer, som er kulturtypiske. Store sociale grupper danner sig efter bestemte principper, hvor gruppestrukturen i samfundet ændrer sig efter et bestemt mønster. Arbejds- og knaphedssamfundet er blevet til et overflodssamfund. Der er sket en æstetisering af hverdagen, en opbrydning af det gamle samfund hen imod et oplevelsesorienteret samfund. Det er et samfund, der ikke længere er bestemt af en økonomisk, men af en psykofysisk semantik.

Massekulturen manifesterer sig ikke kun ved de mange millioner forskellige tegn, men også, hvad der ifølge Schulze er sociologisk vigtigere, på de subjektive tydningers plan. Hermed træder vi ind i et samfund, der til stadighed producerer flerdimensionale strukturer i det kollektive betydningsrum. Dette medfører ifølge Schulze også oplevelser, der er rettet mod den enkeltes subjektivitet, og som det ikke er muligt at meddele i ord.

Schulzes store undersøgelse af det vesttyske samfund viser, hvad der er karakteristisk for oplevelsessamfundet i Vesten i slutningen af det 20. århundrede. »Subjektet « bliver præget af serier af oplevelsestilbud, der forbinder sig med livsnødvendige systemer af oplevelses- og bevidsthedsprocesser. Livsnødvendige, fordi de er indlejret i basale psykiske og fysiske strukturer.

De forhold, der især har forandret sig, er samfundets $\varnothing$ konomi og tjenesteydelser. Det bliver tydeligt i reklamer - billeder på den oplevede virkelighed. Tidligere var det brugsværdierne, der var afgørende, man købte således, at ting kunne holde i mange år, stofligheden og materialet var af stor betydning. I dag handler det mere om, hvorledes tingene tager sig ud.

Det er forandringer, som har stor betydning for hverdagslivets udformning. Vi befinder os i et samfund i hastig bevægelse. Et samfund, der for mange er ensbetydende med velstand. Et fritidssamfund, der tvinger os til nye konventioner. Forholdet mellem arbejde og frihed har ændret sig radikalt, bevægelsen mellem livsstilgrupper er radikalt anderledes. Den enkeltes handlingsfelt kan veksle og rette sig mod flere felter, er mindre låst og vilkårligt i forhold til tidligere. Men der er noget, der tyder på, at man også er mere sårbar i et samfund, hvor den enkelte i større udstrækning er 
orienteret mod de umiddelbare handlingsfelter - med fare for at blive opslugt af det flygtiges iscenesatte betydningsproduktion.

De radikalt ændrede forhold i samfundet og de mellemmenneskelige relationer i de sidste 20-30 år kan bl.a. konstateres i følgende:

- Opløsning af proletariske miljøer og traditionelle klasseopdelinger.

- Afvikling af fastlagte standarder af livsforløb - mand, kvinde - børn.

- Tab af betydning for traditionelle sociale hierarkier.

- Individualisering som følge af optrævling af klassebestemte socialisationsmønstre.

En ny tidsalder fortjener mere end blot at blive betegnet med begreber som postmoderne, senmoderne m.m. Vi må analysere de vilkår og billeder, der er fremherskende i vor tid for at kunne forstå sammenhængen.

Det er vigtigt at være opmærksom på, hvor meget samfundet ændrer sig, og hvad det er for processuelle mønstre, der er med til at præge menneskers livssammenhænge. Vi må orientere os mod både de forskellige historiske forudsætninger og de umiddelbare livsmønstre, som mange finder naturlige i slutningen af det 20. århundrede.

De teoretiske modeller, som vi kender fra de store klassiske $\varnothing$ konomer og sociologer som Adam Smith, Karl Marx og Max Weber, kan ikke længere bruges til at beskrive og forklare dé samfundsmæssige dynamikker og individuelle livsstilsmønstre, som Gerhard Schulze har gjort rede for under betegnelsen oplevelsessamfundet. Klassesamfundet og idealtyperne i Webersk forstand tilhører fortidens sam- fundsformationer. Abstraktionerne fra Marx og Webers tid duer ikke længere. Det kommer specielt frem inden for sociologien på felter som idræt og sport.

Vi må prøve at udvikle viden, der kan tjene som orientering, idet mange farer vild i denne tilbudsgivende livssituation, som ifølge Gerhard Schulze er blevet så dominerende i løbet af de sidste årtier. Det handler om flygtighed, desorientering og splittelse over for fordybelse, viden og forståelse for de sociale potentialer, vor tid rummer.

\section{Sociologiens problem- aktuelle farer}

Sociologien har lige siden sin opkomst som selvstændig videnskab undergået utallige forandringer og specialiseringer. Den hollandske sociolog Johan Goudsblom har i en bog fra 1977, Soziologie auf der Waagschale $^{2}$, unders $\emptyset$ gt udviklingen inden for sociologien fra fagets opkomst som særligt forskningsfelt i sidste århundrede til dets forgrening i utallige institutionaliserede specialdiscipliner i sidste tredjedel af dette århundrede.

Han mener, at hvis man ser på den forvirring, der er indenfor feltet, kunne man fortvivle. Sociologien har udviklet sig til en mængde usammenhængende fragmenter. Den stærke arbejdsdeling har medført, at sociologernes egne sociale felter også er splittede, disparate og uoverskuelige.

Han prøver at trække forskellige teoretiske traditioner og linier op og formulerer i den forbindelse problemet:

Kan sociologien som forskningsfelt hjælpe os med at forstå og gennemskue vores livssammenhænge, eller ender det i en masse billeder og begreber, som forvirrer os! 
Goudsblom konstaterer, at vi får masser af data, men det kniber med sammenhængen. De enkelte sociologer konstituerer sig i egne specialområder med konferencer, tidsskrifter osv. En specialisering, som øger og uddyber føromtalte fragmentering af krop og bevidsthed.

Der har været et utal af ismer, som mere har været orienteret mod andre ismer og ideologiske overbevisninger end mod kropsoplevede vilkår og menneskers processuelle livsbetingelser.

Hverken ideologier eller data er nok til at forstå samfundsudviklingen. Goudsblom plæderer for, at det er vigtigt af få udviklet modeller, der kan bruges som orienteringsmiddel $\mathrm{i}$ forskellige af de særligt strukturerede samfundsområder for derved bedre at kunne forstå, hvad sociologi grundlæggende går ud på.

Norbert Elias (1897-1990) udtrykker i en række upublicerede skrifter fra 80'erne også sin bekymring over udviklingen inden for de etablerede sociologiske skoledannelser. ${ }^{3}$ Han mener, at de ansatte i de videnskabelige institutioner samler og beslaglægger mere og mere viden, samtidig med at de blokerer for en koordination af de mange discipliner. De enkelte grene i sociologien spalter sig i autonome grupperinger med egne specialer, hierarkier og institutionaliserede forskningspolitiske magtkampe. Ofte med stærk tilknytning til interesseorganisationer eller politiske partier.

Det er modsætninger, som er uheldige i forhold til de store opgaver, der venter sociologien. Den vanskelige situation, som sociologien befinder sig i, kommer ifølge Norbert Elias til udtryk på følgende måder:

1. De mange specialområder såsom industrisociologi, udviklingssociologi, kultursociologi, sportssociologi, religionssociologi og det ubekendte, som man kalder almen sociologi, kan reelt ikke kommunikere med hinanden. De optræder som sidestillede bindestregssociologier uden en fælles referenceramme, hverken kategorialt eller i forhold til en centralteori, der henviser til genstandsfeltet sociologi.

Bindestregssociologien blokerer for sociologiens udvikling, fordi den indskrænker muligheden for kooperation mellem repræsentanterne for specialsociologierne. Det skyldes bl.a. den indbyrdes uafklarethed imellem dem og den statususikkerhed, der hersker inden for sociologien som fag. De rivaliserende grupperinger udvikler et specialsprog inden for hver deres speciale, som $g ø r$ arbejdet med andre bindestregssociologer yderst vanskeligt eller umuligt.

Den begrænsede status, som sociologien har i samfundet, gør, at man læner sig op ad fagdiscipliner, der har en højere status i det videnskabelige hierarki. Eller man overfører respektløst viden fra et fagområde til et andet uden at gøre sig klart, at sociologien og dens genstandsfelt hænger uløseligt sammen i dynamiske processer, der undergår bestandige forandringer.

2. Teoretiske sekter udvikler en særlig sproglig og kategorial kanon, som medlemmerne magtpolitisk står som repræsentanter for. Disse sekter er så forskellige, at en diskussion mellem dem næppe er mulig. De går under betegnelser såsom handlingsteoretisk sociologi, fænomenologisk sociologi, etnometodologisk sociologi, systemteoretisk sociologi og eklektika. Man betragter andre teorier og sekter som modstandere, ja fjender med dertil hørende stigmatiserende udtalelser og kommentarer til de andres arbejde. Det er disputter, der ofte foregår på et så højt abstraktionsniveau, at udenforstående har svært ved at forstå, hvad det egentlig drejer sig om, da mange af de teoridannelser, der vokser frem på de højere læreranstalter, er meget 
komplekse, vanskelige og tidskrævende at sætte sig ind i.

3. Nogle sociologiske teoridannelser læner sig op ad prestigefyldte fag, komplicerede filosofiske systemer eller naturvidenskabelige designs og settings, der præger form og indhold i den måde, man skriver på.

4. Sociologiske teorier politiseres, således at de enten kommer til at tjene en politisk ideologi eller er systembevarende for forskellige former for statsadministration. Der findes marxistiske teoretikere, liberale teoretikere, konservative teoretikere m.m.

De to store politiske teorier og systemteorier negligerer sociale konflikter og spændinger og taber således sensibiliteten over for den subjektive forankring og forandring. Den atomistiske problemstilling tillader ikke bestemmelsen af magtforhold. Og udarbejdelsen af de mønstre, der synliggør magtbalancerne mellem etablerede og outsidere.

Afhjælpningen af denne misère og udviklingen af en sociologisk centralteori hører ifølge Norbert Elias til de vigtigste opgaver i fremtidens sociologi.

\section{Om sociologiens genstandsfelt}

Lad os på baggrund af ovennævnte overvejelser vedrørende såvel forvirringen og fragmenteringen $\mathrm{i}$ oplevelsessamfundet som sociologiens mange specialiseringer og forgreninger prøve at komme væsenet sociologi til livs.

I sine upublicerede notater vedrørende felterne sociologi og videnssociologi kredser Norbert Elias omkring denne problematik.

Han mener, at når man stiller spørgsmålet: Hvad er sociologi?, er det ensbetydende med, at man stiller spørgsmålet: Hvad er sociologiens genstandsområde?
Sociologiens opgave er sammen med andre former for videnskab at gøre den endnu ikke begrebne verden, som alle forefinder, mere tilgængelig for menneskers forståelse. Sociologien har som andre videnskabelige discipliner til opgave at sikre det lager af viden, som mennesker har samlet til erkendelse af den ukendte verden. De forskellige videnskaber har også til opgave at fordele denne opgave imellem sig. De er henvist til at udforske forskellige regioner for at åbne for ny indsigt og forståelse af det, som endnu ikke er kendt og erkendt.

Så når man spørger: Hvad er sociologi?, må man først og fremmest finde frem til, hvad det er for et genstandsområde, sociologen beskæftiger sig med. Bestemme, hvad det er for en opgave, der er særlig for den, og som den bør være i stand til løse. Dens område er ikke statisk, kan ikke fikseres i ubevægelighed. For sociologiens genstandsområde er os selv som mennesker.

Sociologien retter sig mod et felt, som menneskene først relativt sent har forstået som åbent for videnskabelig udforskning, nemlig de samfund, som mennesker danner med hinanden.

Ældre videnskaber som fysik og biologi har samlet en kontinuerlig strøm af viden, som de på trods af deres specialisering kan formidle til hinanden, da de besidder en centralteori. Sammenhængskraften i den fysiske videnskab betyder, at udviklingen $\mathrm{i}$ specialdisciplinerne bliver frugtbar, idet de kan føres tilbage til en forpligtende referenceramme, som er alles forudsætning. Den er fælles for såvel Albert Einstein som Niels Bohr.

Sociologien, som er et relativt autonomt genstandsfelt, opererer på et andet forklaringsniveau, hvor man opfanger variationer og forandringer i menneskenes for- 
ståelse af de processer, som de i praksis udvikler i forhold til hinanden. Der findes ingen ophavsmand eller evigt gyldige lovmæssigheder. Der bliver i sociologien stillet spørgsmål til forandringer. Variationer og forandringer i forløb.

Sociologien skal involvere sig i livssammmenhænge, hvor tingene ikke blot er eksterne, men danner dynamiske spændingsfelter - hvor de herskende vilkår præger menneskene, deres psykiske og fysiske habitus. Opgaven er da at udvide synsfeltet og udvikle et sprog, der er egnet til at beskrive hændelser, som er til diskussion, men trods alt kan føres tilbage til en historisk sammenhæng.

Dette gælder også bevidstheden om sociologiens samfundsmæssige funktion. Dens problemområde er vanskeligt at bestemme og nå til fuld klarhed over. Men det er vigtigt, at erkendelsen af de enkelte momenter indføjes i større mønstre og sammenhænge.

Det falske filosofiske spørgsmål lyder: Hvorledes kan et menneske som subjekt for erkendelsen vinde gyldig eller sand viden fra et objekt? Erkendelsesprocessen er en social proces, som løber over generationer, og den underliggende betingelse er to fundamentale ændringer i det filosofiske scenarium.

I stedet for et enkelt individ som subjekt for erkendelsen træder en hel gruppe af mennesker - ikke bare her og nu, men over mange generationer. Subjektet for erkendelsen forbliver ikke uforandret, når det får mere viden. »Subjektet« selv ændrer sig i takt med erkendelsesprocessen. Dette er et centralt punkt i den fremtrædende tyske psykoanalytiker Alfred Lorenzers socialisationsteori. ${ }^{4}$ Mennesket er en proces, hvor de sanselige interaktionsformer bliver båret af matricer, mere eller mindre fleksible handlingsudkast, der også rodfæster sig som sociale figurer i den biologisk-fysiologiske proces.

At menneskene ændrer sig i løbet af erkendelsesprocessen, må de teoretiske modeller, der benyttes kunne opfange. Ændringer i situationer og processuelle forløb må inddrages i refleksionen.

\section{Auguste Comtes systematiske studium af menneskene og det samfund, som de former}

Sociologiens fader Auguste Comte, 17981857, skrev fra 1830 til 1842 Cours de philosophie positive. ${ }^{5}$ Med dette værk i tre bind ville han løsrive den menneskelige erkendelse fra religionen og befri menneskene fra de metafysiske forestilinger, der styrede deres samfundsmæssige orientering. Han tilstræbte en model, der kunne vise de samfundsmæssige lovmæssigheder med samme stringens og præcision som matematikken og naturvidenskaberne. Dette skete parallelt med den stadig mere udviklede og komplekse naturvidenskab, hvor indsigten i lovmæssigheder materialiserede sig i evnen til at beherske tekniske og fysiske processer.

Det er vigtigt at se nærmere på den problemstilling, som Comte var så optaget af, nemlig at vise, at videnskabelig erkendelse foregår i et samspil mellem teoretisk viden og empiriske iagttagelser.

Comte fik stor betydning for sociologiens udvikling. Han har ydet et vigtigt bidrag til udviklingen af forståelsen af det menneskeskabte samfund. Vi går derfor tilbage til ham og ridser op, hvad det er for erkendelser og viden, han har banet vejen for. Han kan også bruges som eksempel på, at videnskabelig erkendelse er alt andet end retliniet. 
Comte fortjeneste var at vise, at erhvervelse af viden foregår ved hjælp af teorier og empiriske iagttagelser. Norbert Elias gør i bogen Was ist Soziologie? opmærksom på, at August Comte har gjort meget mere for sociologien end at give den navnet. Han mener, at Comte har bidraget med erkendelser, der har betydet meget for sociologien og moderne erkendelsesteori.

Mange forskere har ment, at Comte var positivist. Ved positivist forstår man normalt en forsker, der er repræsentant for den videnskabsteoretiske forestilling, at man ved videnskabeligt arbejde eller erkendelse i det hele taget kan udgå fra iagttagelser for da på et senere tidspunkt at konstruere teorien. Det er en fremgangsmåde, moderne forskere ofte gør grin med og kalder flad positivisme. Man betvivler, at man kan foretage iagttagelser af værdi, hvis man ikke på forhånd råder over en teori, som sætter en i stand til at udvælge og sortere de iagttagelser og problemstillinger, som man, via sine iagttagelser, søger at finde et svar på. Ordet positiv blev i det store og hele benyttet af Comte som synonym for videnskabelig. Herved forstod han erhvervelse af viden ved hjælp af teorier og empiriske iagttagelser.

Norbert Elias forsvarer Comte med følgende citat fra Cours de Philosophie Positive:

»Selv om man på den ene side nфdvendigvis må fundere en positiv teori på iagttagelser, så er det ikke mindre rigtigt, at vores forstand beh $\phi v e r$ den ene eller anden teori for at kunne iagttage. Hvis man ved betragtning af fanomener satter disse $i$ et umiddelbart forhold til visse principper, vil det ikke kun vare umuligt for os at bringe disse isolerede iagttagelser $i$ forbindelse med hinanden ... vi vil endog vare fuldstandig ude af stand til at erindre os de relevante kendsgerninger. Man vil for en stor dels vedkommende ikke marke sig iagttagelserne ${ }^{6}{ }^{6}$

Denne stadige og samtidige forholden sig til to tankeoperationer, der retter sig dels mod en teoretisk sammenfatning, dels mod empiriske iagttagelser, hører til Comtes grundtese. Og hermed adskiller Comte sig fra det, man i vore dage forstår ved en positivist.

Comte troede ikke på, at man ved videnskabeligt arbejde kunne gå rent induktivt til værks. Dvs. gå ud fra iagttagelser og enkelte kendsgerninger på baggrund af rene løsrevne iagttagelser og så bagefter danne en sammenfattende teori. Han tilbageviste med lige så stor konsekvens denne opfattelse som den, at man kunne gå ud fra teorier eller hypoteser, der ikke var relateret til særlige iagttagelser. Han gik dermed også imod rent spekulative og vilkårligt dannede teoretiske konstruktioner, der først bagefter blev bekræftet og prøvet af ved hjælp af konkrete, enkeltstående kendsgerninger. Den fremgangsmåde, hvor man forudsætter en teori og en hypotese, og så bagefter finder de kendsgerninger, som bekræfter det, der allerede er forudsat.

Der findes utallige eksempler på dette inden for det, der betegnes som en psykologisk eller logisk forståelsesmodus. Der er gode grunde til, at Comte brød med disse filosofiske traditioner og tænkeoperationer, som i århundreder har kæmpet mod hinanden under betegnelser som deduktionister og induktionister, rationalister og empirister, apriorister og sensualister.

Det er denne nye erkendelsesteoretiske orientering, som er ensbetydende med, at man ikke kommer langt med at konkludere, at Comte med betegnelsen sociologi blot fandt et nyt navn for begrebet sociofy- 
sik. Han fandt navnet sociologi, fordi han erkendte, at videnskaben om samfundet er en ny form for videnskab, som ikke lader sig bringe under samme hat som fysik og biologi. Han foretog et brud med den klassiske tænkende rationalitet og brød vej fra den filosofiske til den sociologiske erkendelse.

\section{Den klassiske erkendelses- og videnskabsteori og den sociologiske teoris erkendelse}

Den klassiske erkendelses- og videnskabsteori undersøger, hvorledes et subjekt, et enkeltmenneske tænker og erkender, når det udfører videnskabeligt arbejde. Comte brød med denne tradition, idet han mente, at den var uforenelig med de kendsgerninger, man kunne iagttage.

Tanke- og forskningsvirksomhed er en kontinuerlig proces, der strækker sig over generationer. Det enkelte menneskes arbejde med videnskab bygger altid på tidligere generationers. Derfor er det vigtigt, at man både forholder sig til traditionen og den strøm af virkelighedsmønstre, som man er en del af. Det gælder både den materielle og den kropslige virkelighed. Tænk på de normer og den viden, der eksisterede under vore forfædres opvækst, hvordan hverdagen så ud i 1700-tallet, i 1800-tallet. Hvilken forskel til vilkårene i vort århundrede.

For at kunne forstå, hvorledes mennesker går til værks ved tænkning, erkendelse og videnskabeligt arbejde, må man ifølge Comte undersøge eller i det mindste have kendskab til den lange samfundsmæssige proces, der har præget udviklingen af menneskers tænkning og videnserhvervelse. Norbert Elias udtrykker det således:
»Overgangen fra en filosofisk til en sociologisk teori, der vedrører teori og erkendelse $i$ videnskaben, viser sig først og fremmest $i$, at subjektet for erkendelse ikke tager afsat $i$ det enkelte menneske, men $i$ det menneskelige samfund «. ${ }^{7}$

Selv om problemet omkring tænkning står i centrum for Comtes sociologiske problematik, så lykkes det ham at sociologisere forestillingen om det tænkende subjekt. Det er et radikalt opgør med den type tænkning, som var og er den herskende europæiske filosofi, og som klarest kommer til udtryk som rationel tænken i naturvidenskaberne. Det er den, som kommer til at tjene som grundlaget for videnskabelig tænkning. Denne form for videnskabelig tænkning træder i den menneskelige udvikling for alvor frem i renæssancen. Den hævder, at alle andre former for erkendelse end den rationelle i naturvidenskaberne er førvidenskabelig.

Comte gør opmærksom på, at al erkendelse, også den videnskabelige, udspringer af tanker og erkendelser, som ikke er videnskabelige. Den proces, som Comte bringer ind i erkendelsesteorien, blev ikke for alvor medinddraget i den klassiske erkendelsesteori. Det er i den sammenhæng, man skal se den udviklingsmodel, Comte opstiller for erkendelsens tre stadier.

1. Det teologiske - det fiktive stadium.

2. Det metafysiske - den abstrakte erkendelse.

3. Det videnskabelige eller positive stadium.

Den tænkning, som mennesker benytter, når de udforsker verden - det er Comtes grundtese - bevæger sig igennem disse tre forskellige systemer eller stadier med hver deres egenart. Når man som referenceram- 
me har menneskehedens tænken og erkendelse og ikke et enkelt menneskes, får man del i en erkendelse, der bevæger sig gennem serier af generationer. Her udvikles menneskers tanker om den livløse natur, den levende natur og endelig om samfundet.

Den viden, der bygger på mekaniske lovmæssigheder, tager ofte udgangspunkt i absolutte til alle tider gældende normer. De absolutte normer kan som erfaringsgrundlag blive til dogmatiske svar, der henviser til en ophavsmand eller påberåber sig abstraktioner som naturen, fornuften osv.

Den positive tænken i Comtes udformning opgiver forestillingen om ophavsmanden. Selv opfattelser, som er oplevelsesorienterede, bliver suppleret med viden og erfaringer, der kan føres tilbage til processer og sammenhænge i den konkrete virkelighed. $\mathrm{Nu}$ om dage kalder man denne form for sammenhænge for lovmæssigheder, strukturer eller funktionssammenhænge.

Opgaven er da at vise, hvorledes disse er sammensat og forbundet med ændringer i samfundsstrukturerne. Det interessante er at finde ud af, hvordan disse typer af viden bliver til videnskabelig erkendelse. Det er bl.a. det, videnssociologien handler om.

Forfølgelsen af tankens historie er relevant for forståelsen af opkomsten af erkendelsesmønstre. For forståelsen af vore begreber og ikke mindst det sprog, vi bruger til at fastholde og videreføre viden. Hvis mennesker ikke har den viden, der er nødvendig for at indlede ovennævnte proces, hvor viden fungerer som orientering, akkurat som et landkort, bliver erkendelsen repetitiv, uafgrænset, endeløs. Og det, man ikke ved noget om, bliver gerne overladt til fantasien eller den herskende magtelite.

\section{Den videnskabelige forskning af videnskab}

Den filosofiske tradition vedrørende erkendelse og videnskabsteori beror på en hypotese over forholdet mellem tænkeform, måden at tænke på og indholdet af tænkningen. Norbert Elias udtrykker betydningen af denne problematik således:

\begin{abstract}
»Det handler om forholdet mellem kategorier (grundelementerne, hvorpå erkendelsen hviler: grundbegreb, klasse, rubrik, slags osv.) og vidensindhold, om den videnskabelige metode og videnskabernes genstande. De er baseret på en hypotese (videnskabelig antagelse), der som noget selvfølgeligt uformidlet bliver givet videre fra den ene generation til den naste. Det vil sige bliver overfort uden at vare blevet afprøvet på den virkelighed, man unders $\phi g e r \ll .{ }^{8}$
\end{abstract}

To eksempler. Jorden er flad. Menneskene nedkommer fra Gud. Tænkeinstrumenter, som er statiske. Sådanne hypoteser siger, at menneskers måde at tænke på er den samme i al evighed, også selv om det, der analyseres, er meget forskelligt. Denne antagelse går igennem som en rød tråd i mange unders $\emptyset$ gelser og diskussioner i den filosofiske lære om videnskaben. Det bliver her antaget som videnskabeligt, når man benytter en bestemt videnskabelig metode helt uafhængigt af den specifikke karakter, som det genstandsområde, man undersøger, besidder.

Comte vendte sig mod denne adskillelse af form og indhold - mod adskillelsen af videnskabsmetode og vidensgenstand - af tankning og viden. Metoden må i stedet være smidig og variabel og svare til den særlige egenart og kompleksitet, som fænomenerne og undersøgelsesfeltet udviser. 
Comte havde hermed henvist til et problem, som med tiden er blevet fuldstændig skrinlagt, nemlig spørgsmålet mellem toenkeform og viden.

Overgangen fra en filosofisk til en sociologisk videnskabs- og erkendelsesteori, som Comte indledte, beroede bl.a. på, at han ikke mere spurgte, hvordan en videnskab skulle gå til værks, men undersøgte de dominerende karakteristika ved den videnskabelige fremgangsmåde og forskellen mellem den førvidenskabelige tænkning og den videnskabelige.

Norbert Elias, som jeg her refererer til, mener, at den filosofiske sammenblanding af ideal og kendsgerning, ophøjelsen af metoden fra en bestemt enkeltvidenskab, nemlig den klassiske fysik, til den videnskabelige metode overhovedet, indtil i dag har været en forhindring for sociologiens selvstændige udvikling. Den traditionelle filosofiske problemstilling er ego-centrisk, fordi den begrænser sig til spørgsmålet, hvorledes et enkelt menneske får eller vinder videnskabelig erkendelse. Men det enkelte menneske har allerede gennemlevet bestemte læreprocesser og socialisationsprocesser, hvor det har lært eller fået indoktrineret bestemte former for tanker, specifikke kategorier af særligt tilsnit, der sætter vedkommende i stand til på forskellig måde at bringe enkeltiagttagelser i forbindelse med hinanden. Det problem, der rejser sig, er om den traditionelle adskillelse mellem uændrede tænkeformer og foranderlige vidensindhold overhovedet har en berettigelse.

Det er Comtes fortjeneste at opgive den naive ego-centriske filosofiske tradition og erkende, at den førvidenskabelige tænken, der er knyttet til hoendelser og iagttagelser, er forudsatningen for videnskabelig toenkning. I den sammenhæng må man også se hans opstilling af modellen for de tre stadier.
Den teologiske og metafysiske tænkning, den primære og spontane, er forudsætningen for den videnskabelige, også selv om den ikke umiddelbart synes forenelig med realitetsorienteret og stringent tænkning.

Der er to planer, dette kan forstås på. Det umiddelbare, som er udgangspunktet, når man går i gang med at undersøge en problemstilling. Da finder man et tema, som optager en, og begynder at samle data, hvorefter man arbejder metodisk og teoretisk med dette materiale, sådan som det er tilfældet nu om dage. Men det er ikke det, sagen her drejer sig om. Det er mere, at mange har glemt, hvorledes menneskehedens viden og tænkning har udviklet sig fra at være førvidenskabelig til at blive videnskabelig. På det tidspunkt, hvor den var blevet etableret som videnskabelig, optrådte denne form for tænkning som noget rationelt givet, som var gyldigt i al evighed. Verden havde sin rette form, sin rette forståelse. Lige så sikkert som at jorden var verdens centrum, flad og ubevægelig.

Det medfører, at de, der har rådighed over denne viden og behersker den, giver andre det indtryk, at deres fornuft er naturgiven. Objektiv og fuldstændig uafhængig af deres opdragelse, af det samfund, de er vokset op i. Det er med andre ord en viden, der er fuldstændig uafhængig af den historiske og samfundsmæssige udvikling.

Det gælder både den affektive og intellektuelle side - krop, sansning og forstand. Hermed har man overtaget tankemønstre, der er udviklet over flere hundrede år, og gjort dem til statiske og evige kategorier. Men, som vi på forskellig vis har været inde på, må enhver, der begynder at undre sig over sin omverden, begynde på et førvidenskabeligt plan. Det, der var særligt for den videnskabelige tænkning, var, at den var opstået i forbindelse med den na- 
turvidenskabelige erkendelse og derfor blev forstået som rationel.

Comte drager nogle konsekvenser heraf, når han bringer den mytiske tænkning $\mathrm{i}$ forbindelse med militær- og præstestyre som formationer, der sætter normerne for menneskers adfærd og eksistens. Statiske opfattelser af menneskers liv og placering i det eksisterende samfund optræder som videnskab. Nogle er født til at slide og slæbe, andre til fastlåste positioner, som var de led i en ubønhørlig orden som den, der undersøges af den naturvidenskabelige forskning. Selv i dag søger man at begrunde den samfundsmæssige struktur i biologiske og psykologiske konstanter.

Det må fastholdes, at sociologien er en autonom videnskab. Selvfølgelig skal videnskaberne forholde sig til hinanden, men de integrations- og funktionssammenhænge, der aftegner sig i den samfundsmæssige udvikling, er yderst komplekse. Det menneskeskabte samfund hviler på forviklinger af interdependente mennesker på et meget komplekst integrationsniveau, hvor processer og strukturer ikke umiddelbart kan afledes af de biologiske og psykologiske ejendommeligheder, der kendetegner menneskene.

Spørgsmålet: Hvilken funktion har sociologien og andre orienteringsmidler for hvilke grupper, hænger sammen med den funktion, den kan have for forskellige grupper. Og sammenhængende hermed: Af hvilken art er den sociogenetiske processualitet, der gennemtrænger samfundsmæssige strukturer og forløb?

Et problem i det 20. århundrede er, at selv om en stor del af befolkningen nyder en relativ høj grad af fysisk sikkerhed, lider den under angst og forvirring. Det er en angst og rådvildhed, der udvikles i relationerne mellem forældre, ægtefæller, børn, naboer, venner, kollegaer og konkurrenter.
Sociale mikroprocesser, som fastholder menneskene i en tvangssituation.

Johan Goudsblom benytter især Norbert Elias' proces- og figurationssociologi som udgangspunkt og begrundelse for en ny orientering inden for det sociologiske felt. Han gør det ud fra følgende konstateringer:

»1. Mennesker er afhongige af hinanden og det på mange måder og planer. Deres liv udvikler sig inden for de sociale figurationer, som de danner med hinanden, og som på signifikant måde prager dem.

2. Disse figurationer er $i$ stadig bevagelse, de er altid under forandring. Nogle forandringer er hurtige og forbigående, andre langsomme og måske af langere varighed.

3. De langfristede udviklinger i figurationer var og er for storstedelens vedkommende ikke planlagte og er vanskelige eller umulige at forudse.

4. Udviklingen af den menneskelige viden finder sted inden for sådanne figurationer og er et vigtig moment $i$ deres samlede udvikling. Også sociologiens udvikling må ses $i$ denne sammenhang som moment $i$ den fortlobende, ikke planlagte og ikke forudsigelige udvikling $i$ industrisamfundene ${ }^{9}{ }^{9}$

\section{Derfor figurationsanalyser}

»Desvarre er det ikke overflфdigt at gøre opmarksom på, at i sociologien har vi med mennesker at gøre. Alt for ofte begynder sociologer, iscer når de bevager sig på et alment plan, at teoretisere med abstrakte begreber som »social handlen« eller »sociale systemer«. Desuden 


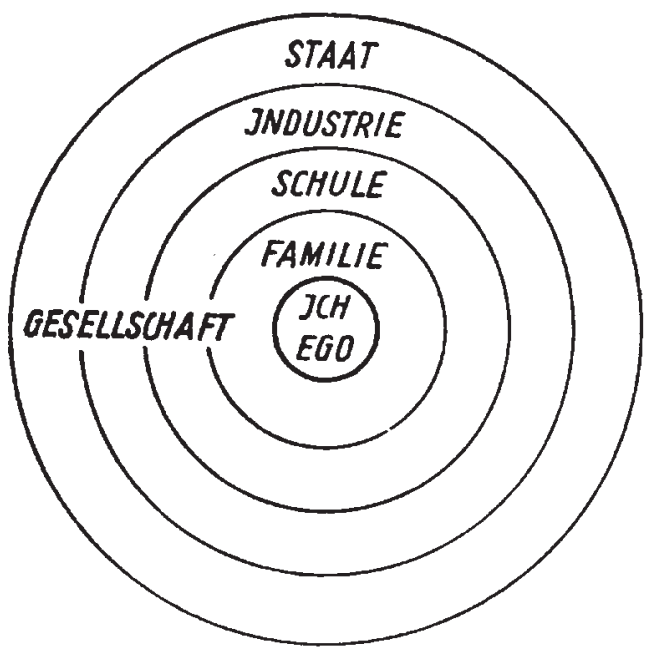

Grundskema af det ego-centriske samfundsbillede. $^{12}$

ser det ud til, at man på forskellige områder inden for socialforskningen får menneskers liv til at forsvinde bag statistiske analyser og kvantitative data. Det er derfor, det har en mening at understrege, at vi beskaftiger os med mennesker, der er forviklet $i$ konstellationer, som er $i$ stadig bevagelse. Og at disse på grund af deres sarlige natur bedst kan betegnes med begrebet: Figuration ${ }^{10}{ }^{10}$

I dette afsnit vil jeg give en begrundelse for, hvorfor det er nødvendigt med en orientering hen mod de såkaldte figurationsanalyser. Jeg vil diskutere aktuelle problemkomplekser og forhåndenværende teoriudkast og derudfra argumentere for en supplerende nytænkning af mellemmenneskelige relationer og institutioner. Samtidig vil jeg søge at give indblik i orienteringsmodeller, der ikke umiddelbart er begribelige ud fra traditionelle sociologiske forestillinger. Jeg vil stille spørgsmålet: Hvorledes kan forskellige institutionelle socialisationsagenturer eller figurationer, som inter- dependente mennesker danner med hinanden, undersøges og beskrives med et selvstændigt empirisk formidlet begrebs- og kategoriinventar. Besvarelsen af dette spørgsmål er efter min mening ledetråden i og den mest perspektivrige kvalitet ved Norbert Elias' sociologiske modeller.

\section{En kritik af det ego-centriske samfundsbillede}

En indføring i Elias' tematik betyder samtidig en kritik af metode og arbejdsform inden for den herskende sociologi. ${ }^{11}$

Det er især to fundamentale misforhold, som Elias fremhæver i sin kritik. - 1. Allerede sprogbrugen er vildledende, idet menneske og samfund bliver fremstillet som statiske enheder. Det kommer til udtryk i brugen af termerne individ og samfund, individ og fællesskab samt begreber som status og rolle. -2 . Den enkelte fremstilles altid som noget, der står over for en omverden, f.eks. en skole, en familie, et samfund. Det er Elias' opfattelse, at denne tilgang blokerer for den kendsgerning, at individet som individ samtidig er en del af sin omverden - sin familie, sin skole, sit samfund. Den traditionelle begrebsliggørelse lader tingene fremtræde »som om det drejede sig om genstande, om objekter af samme art som klipper, traer og huse ${ }^{13}{ }^{13}$ Den tingsliggjorte indflydelse, som vores sprog som nedarvet tænkemiddel øver på vores bevidsthed, har stor indflydelse på, hvorledes vi opfatter forholdet individ/samfund. Denne modstilling er falsk, og opdelingen mellem ydre og indre er blokerende for en dynamisk sociologi.

»Hvis man vil forstå, hvad det drejer sig om $i$ sociologi, da må man vare $i$ stand til i tankerne at traede ud af sig selv og se 


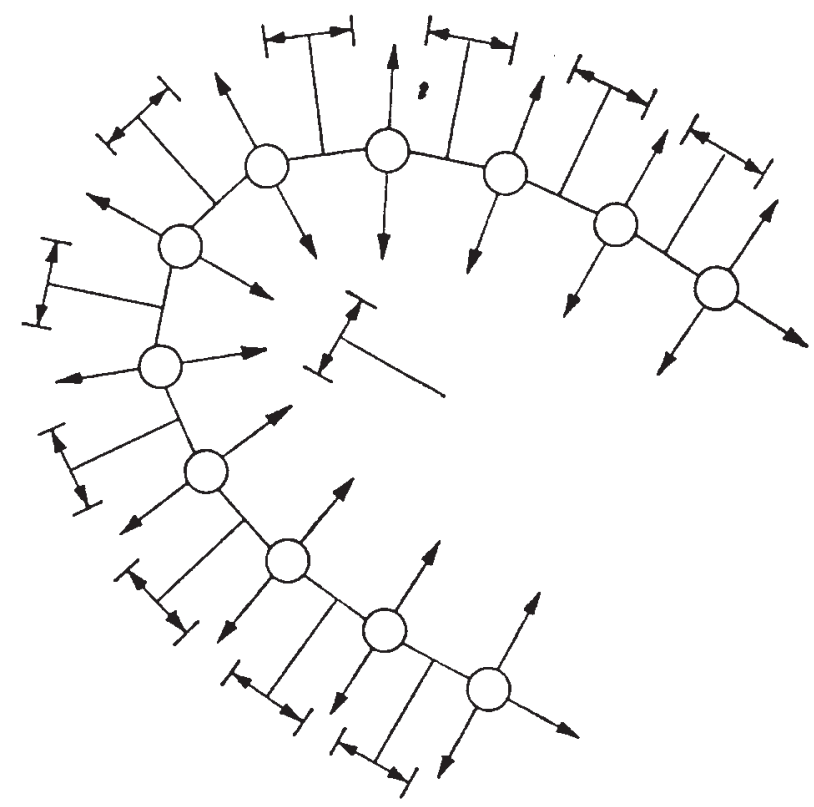

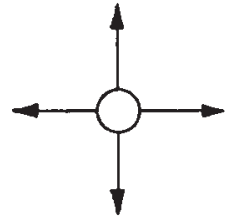

Individuum

$\left(, E 00^{\prime},, J()^{\prime \prime}\right)$

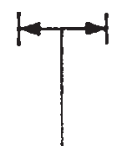

Symbol einer mehr oder weniger labilen Machtbalance

\section{offerie (ungesättigte) Valenz}

"Eine Figuration interdependenter Individuen « skal tjene som en forhåndsorientering og som hjalp for den omorientering, der er en forudsatning for at kunne overskride det isolative, statiske menneske- og samfundssyn-frem mod en dynamisk figurativ opfattelse af menneskelig interdependens.

sig som et menneske blandt andre mennesker. Thi sociologien beskaftiger sig med problemer, der vedrører "samfundet «, og til samfundet hører enhver, der gør sig overvejelser over det og udforsker det. Men for noervarende bliver man, når man toenker sig selv, meget ofte stående på et trin, hvor man kun bliver sig selv bevidst som et menneske, der står over for andre mennesker som »objekter", meget ofte med en folelse af vare adskilt fra dem ved en uoverstigelig klфft. Følelsen af en sådan adskillelse, der modsvarer dette trin i en bliven sig selv bevidst, giver sig udtryk i mange almindelige begrebsdannelser og talemåder, som er med til at få adskillelsen til at fremstå som noget ganske selvføl- geligt, og som bidrager til bestandig at reproducere og forstcerke den «. ${ }^{14}$

$»$ Figuren tjener til at hjcelpe loeseren til $i$ tankerne at gennembryde de tingsliggjorte begrebers hårde facade. Sådanne begreber sparrer $i$ vidt omfang for menneskers klare forstålse af deres samfundsmassige liv og understøtter igen og igen det indtryk, at »samfundet« bestär af formationer uden for »jeg'et«, det enkelte individ, og at dette enkelte individ på en og samme tid er omgivet af »samfundet" og adskilt fra det ved en usynlig mur ${ }^{16}$

Figuren skal udover at bryde den traditionelle individuelt mystificerede eller objektivt tingsliggjorte sprogbrug illustrere, at 
den enkelte indgår i et netværk af bindinger og afhængigheder. Individerne må gennemskue, at de lever i figurer, der ikke er neutrale; tværtimod hersker mere eller mindre labile magtbalancer, som er dannende for den enkeltes vi-billede og udformningen af den enkeltes valensstruktur og relative autonomi.

Disse selvorienteringsinstanser er ikke identiske med jeg-strukturer, jeg-billeder, men er et supplement til det, Freud på individets niveau forstår ved identitet. Vi udvider jeg-identiteten med et vi-billede, der ikke er tilfældigt struktureret, men i høj grad afhængigt af den enkeltes figurative interdependens. De er også et udslag af de til enhver tid herskende magtrelationer inden for den figur, man er en del af. Figurationen præger vores fællesskabsfølelse, loyaliteter, identifikationsmønstre, jeg- og vi-ideal, fjendskaber og tænketradition. Ved at være de strukturejendommeligheder bevidst, som hersker i de figurationer, som individerne indgår i, udvides orienteringsog sprogfeltet $\mathrm{i}$ en helt anden størrelsesorden, end når vi mekanisk hypostaserer tanker og symboldannelser, hentet fra traditionelle tilgange.

Med figurationsanalyser kommer vi til at ændre vores opfattelse af menneskerelationer som noget, man kun kan tanke $i$ enten singularis eller pluralis, og kan derved forklare de særlige dynamikker, som figurationsstrømmen implicerer. Det drejer sig om at ophæve den mur, der traditionelt eksisterer, når mellemmenneskelige problemer og konflikter undersøges.

»Entalsformen »menneske« blokerer for nogle enkle, men vigtige sociologiske indsigter. Samfund er pluraliteter af interdependente mennesker. Den »tvang", som angiveligt udфves af »sociale institutioner «, bliver de facto udфvet af mennesker. Lige pracis de samme personer, som måtte fole sig udsat for en frygtelig »tvang «, фver selv aktivt tvang; de satter andre mennesker og sig selv under pres ${ }^{17} .{ }^{17}$

Erkendelsesteoretisk er der også gevinster ved at opgive den rigide fremstillingsform, hvor den enkelte står over for de mange. Det er altså ikke blot af saglige grunde, at denne modstilling bør overvindes, faglige motiver spiller også en rolle. Kunstige faggrænser kan ikke opretholdes uden at komme til at blokere for undersøgelser af den art, som tematiseres i denne artikel. Ofte når det enkelte menneskes problemer søges løst, f.eks. ud fra en psykologisk eller psykoanalytisk tilgang, bliver baglandskabet, som implicit hører til personens socialisationsagentur, reduceret til en ustruktureret omverden med benævnelser som miljø og lignende og dermed trængt ud i problemfeltets udefinerbare periferi.

»Det enkeltstående »menneske« tjener ofte som modstykke til en meget abstrakt forestilling om »samfundet « som en anonym, fuldstondig afpersonaliseret funktionssammenhoeng. Det er denne tendens, der gфr sig galdende, når man $i$ avisledere og politiske taler henviser til »krafter«, »strukturer« og « systemer«, som begranser »menneskenes" frihed. Den samme modstilling ligger til grund for en stor del af den sociologiske tankning ${ }^{18}{ }^{18}$

Figurationsanalyser er også et forsøg på at ophæve et enkelt fags monopolstilling eller monopolisering af et givet undersøgelsesfelt. Tingene lader sig ikke alene anskue og analysere under en bestemt psykologisk, historisk, økonomisk eller sociologisk synsvinkel. 
»Man kan, når man analyserer menneskene, snart rette det skarpe projektørlys på enkelte mennesker, snart på de figurationer, som mange enkelte mennesker danner indbyrdes. Men forståelsen af begge de betragtede niveauer lider skade, hvis man ikke bestandig tager dem begge i betragtning. Det, som man betegner med to forskellige begreber som »individ« og »samfund «, er ikke, som den nutidige brug af disse begreber ofte lader fremgå, to objekter, der eksisterer adskilt, men forskellige og dog uløseligt forbundne planer $i$ det menneskelige univers. ${ }^{19}$

\section{Spillemodellerne $e^{20}$}

Med figurationer siger vi samtidig »Verflechtungsmodell «. Mennesker, der indgår i en figur, er interdependente. De enkeltes handlinger og ageren indgår i en større orden. I en proces. Figurationsstrømmens spændingsstruktur svarer til de magtrelationer og magtbalancer, som kendetegner figuren.

»Det, man i den forbindelse forstår ved figuration, er de skiftende mønstre, som spillerne, anskuet som en helhed, danner indbyrdes, altså ikke med deres intellekt, men med deres hele person, deres gøren og laden i forhold til hinanden. $\ll^{21}$

For at kunne forklare, hvad vi mener med figurationsstrømmens spændingsstruktur og mønster, de til enhver tid herskende symboler, magtbalancer og magttyngder, og hvad forfletningstvang er, bliver vi nødt til at indføre nogle såkaldte spillemodeller, som Elias har udviklet i bogen Was ist Soziologie? Modellerne tjener også til bedre at kunne forstå symbolsammenhængene i fig. 2.
"Hvad deres teoretiske gehalt end måtte vare, er disse forfletningsmodeller ikke teoretiske modeller i ordets almindelige betydning, men laeremodeller «. ${ }^{22}$

De spillemodeller, jeg her vil præsentere, har også den funktion at gøre vores sproglige redskaber mere sensitive over for det genstandsområde, vi søger at udvikle orienteringsmidler til, idet jeg mener, at vores forhåndenværende sproglige apparatur ikke er fleksibelt nok til at tilvejebringe beskrivelser af den art, som her skal fremlægges. Når vi tænker i balancebegreber, er vi i stand til at iagttage dynamiske funktionssammenhænge og ophæver dermed blokerende begrebsdannelser, der får tingene til at fremstå som statiske. F.eks. bliver processer ofte betragtet og bedømt, som var de i stilstand.

»De modeller, der her beskrives, er med undtagelse af den forste spillemodeller. Deres regler er kunstige. De svarer i deres simplere former til spil som skak, skat, fodbold, tennis eller et hvilken som helst andet »realt« spil. De bliver nyttige, idet de medvirker til opфvelsen af den sociologiske forestillingsevne, som på mange måder blokeres af gangse tankeformer. Disse spil beror ligesom før-spillet, hvis betydning senere vil blive nøjere uddybet, på, at to eller flere mennesker måler deres krafter i forhold til hinanden. Dette er et elementcert sagforhold, som man moder, uanset hvor mennesker står $i$ en relation til hinanden eller trader $i$ kontakt med hinanden, men som man ofte tildakker ved refleksionen over menneskelige relationer - af grunde, som man her ikke behøver at gå narmere ind $p \stackrel{2}{2} .^{23} 24$ 
Hvis procesforløbet og spillets dynamik ses i dets genese og slutresultatet som noget tilblevet, bliver tilstandenes dynamik og historicitet reflekteret og gennemskuet, i stedet for at umiddelbarheden hypostaseres ud over hele forl $\phi$ bet. Modellerne åbner ydermere mulighed for en videnskabelig refleksion over problemet magt.

Når samfundsforhold bliver meget komplicerede, er strukturen i de magttyngder og balancer, som hersker i de figurationer, mennesker danner med hinanden, meget svære at gennemskue. Magt kommer let til at optræde som noget meget diffust. Problemet forplumres og simplificeres ofte derved, at man henfører magtudøvning til enkelte magtkilder, f.eks. militæret, økonomiske systemer m.v. Magten får dermed en udifferentieret blokagtig status. Derved tildækkes det problem, som vi med spillemodellerne søger at vise, nemlig at magtkilder har en polymorf karakter:

»Mere eller mindre fluktuerende magtbalancer er et integralt element $i$ alle menneskelige relationer. De folgende modeller forholder sig til dette faktum. I den sammenhang må man også holde sig for фje, at alle magtbalancer lige som alle relationer $i$ det hele taget mindst er bipolare og for det meste multipolare. Dette vil senere blive nфjere behandlet. Modellerne tjener til anskueliggфrelse af sådanne magtbalancer. Man må gфre sig klart, at også babyen fra den forste dag $i$ sit liv har magt over forceldrene og ikke kun forceldrene over babyen - den har magt over dem, sailange den på en eller anden måde har vardi for dem. Hvis dette ikke er tilfacldet, mister den sin magt - forceldrene kan satte deres barn ud, hvis det skriger for meget. Det samme kan siges om herrens forhold til sin slave. Ikke kun herren udøver magt, slaven har også magt over herren, alt efter den funktion, han opfylder for ham. I forholdet mellem forceldre og spadbarn, mellem herre og slave er magten meget ulige fordelt. Men uanset om magtforskellene er store eller små, så forekommer der magtbalancer overalt, hvor der eksisterer en funktionel interdependens mellem mennesker. Brugen af ordet magt forer os $i$ den forbindelse let på vildspor. Vi siger om et menneske, at han har en meget stor magt, som om magten var en ting, han gàr rundt med i lommen. Men denne sprogbrug er et levn fra magisk-mystiske forestillinger. Magt er ikke en amulet, som den ene ejer og den anden ikke; den er en strukturejendommelighed ved menneskelige relationer - alle menneskelige relationer $\ll{ }^{25}$

Modellerne søger på forholdsvis simpel vis at demonstrere, hvilken dynamisk betydning begrebet magt har i såvel normerede som unormerede sammenhænge. Endvidere må vi være opmærksom på, at hvad der i spillemodellen bliver benævnt relativ spillestyrke, er synonym for begrebet magt. Endelig må der også gøres opmærksom på, at spillestyrke er et Beziehungsbegriff (relationsbegreb).

I fremstillingen og diskussionen af Elias' spillemodeller vil jeg bruge et eksempel med en forfletning mellem 2 stammer, der er unormeret, og derefter fremstille nogle spillemodeller for, hvorledes normerede forfletninger fungerer.

»Den første model viser bestemte aspekter af en total ureguleret relation. Hvis man ikke tager hensyn til disse, glemmer man kun alt for let, hvad der egentlig bliver socialt reguleret ${ }^{26}{ }^{26}$ 


\section{For-spil-model af en unormeret forfletning}

Jeg vil i det følgende redegøre for Elias' før-spilmodel over stammerne A og B. To stammer, der lever i et urskovsområde, bliver i kampen om den stadig mere sparsomme føde involveret i en konflikt med hinanden. Jagtens udbytte bliver for begge stammer af ukendte årsager mindre og mindre. Med den øgede konkurrence om føde opstår der fjendskab mellem stammerne A og B. Den ene stamme B består af store og kraftigt byggede mænd og kvinder, med få unge mennesker og børn. Af ukendte grunde dør mange børn kort efter fødselen. Derfor består denne stamme nu af mange forholdsvis ældre og få unge mennesker. Stamme A, B's modstandere, er mindre og spinklere af bygning, er hurtigere og i gennemsnit væsentlig yngre. $\mathrm{Nu}$ starter en ubønhørlig kamp. De mindre og hurtige folk fra stamme A med de mange børn sniger sig om natten ind i stamme B's lejr og dræber i ly af mørket et stammemedlem og forsvinder derefter hurtigt, uden at de noget langsommere folk fra stamme B er i stand til at forfølge dem.

Stamme B hævner sig efter en vis tid ved at dræbe børn og kvinder fra stamme $\mathrm{A}$, mens mændene er på jagt. Det er under disse »naturlige « betingelser, at disse stammer indbyrdes er afhængige, interdependente; ved at være bundet til hinanden i en bestemt udviklende struktur, udøver de tvang mod hinanden.

»Man står her som ved enhver blot nogenlunde vedvarende relation over for en forfletningsproces. De to stammer kamper om at udnytte chancerne for at bemagtige sig den knappe fode. De er afhoengige af hinanden: Som i et skakspil, der jo oprindelig var et krigspil, be- stemmer hvert trak, den ene stamme foretager, den andens og omvendt. De interne forholdsregler $i$ de to stammer bliver $i$ storre eller mindre grad bestemt af denne indbyrdes afhoengighed. De har en funktion i forhold til hinanden. Interdependensen mellem individer eller grupper af individer, der står fjendtligt over for hinanden, er ikke i mindre grad en funktionel relation end relationerne mellem venner, medarbejdere eller specialister, der på grund af arbejdsdelingen er afhoengige af hinanden. Den funktion, de har i forhold til hinanden, beror $i$ sidste instans på, at de $i$ kraft af interdependensen kan $\phi v e$ tvang mod hverandre. Forklaringen på de respektive stammers handlinger, planer og målsaetninger lader sig ikke finde, hvis man betragter dem som frit valgte beslutninger, som den enkelte stammes planer og målsatninger - dersom man betragter dem hver for sig og uafhoengigt af hinanden. Handlingsmonstrene kan kun bestemmes, hvis man tager den tvang $i$ betragtning, som de $i$ kraft af deres interdependens, deres bilaterale funktion som fjender er i stand til at udøve «. ${ }^{27}$

Elias vil vise, at når mennesker er forviklet i hinandens livsbetingelser, kan der ikke være tale om såkaldte »frie« eller selvstændige planer og afgørelser. Den enkeltes planer og taktikker er altid afhængige af den tvang, som gør sig gældende, hvor mennesker lever i interdependente formationer. Der er et enormt spektrum af afhængighedsformer på grund af de bilaterale og multilaterale funktioner, som fjender og venner har i forhold til hinanden.

»Modellen peger på, at såvel begrebet funktion som begrebet magt må forstås som relationsbegreber. Man kan kun tale 
om samfundsmassige funktioner, når man har at gфre med mere eller mindre tvingende interdependenser. Den funktion, som de to stammer har for hinanden som fjender, viser dette tvangselement ganske tydeligt.$^{28}$

Det drejer sig om at forstå funktionsbegrebet i dets reciprokke aspekt. Man kan ikke forstå A's funktion for B uden at medregne B's funktion for A.

»Det er det, der menes, når man siger, at funktionsbegrebet er et relationsbegreb. Dog ser man det kun klart og tydeligt, når man betragter alle funktioner, også institutioners funktioner, som aspekter af relationer mellem mennesker - hvadenten det er som enkeltindivider eller som grupper.$^{29}$

Samtidig ser man, hvor tæt de funktioner, som interdependente mennesker udvikler i forhold til hinanden, hænger sammen med magtbalancerne inden for denne figur.

Før-spilmodellen anskueliggør selvfølgelig et radikalt grænsetilfælde, idet det her ikke drejer sig om at berøve modparten bestemte funktioner, men selve livet.

Af kampen mellem stammerne A og B fremgår det, at der ikke er nogen fælles normer eller orienteringsmidler til rådighed for stammerne. Magtkilderne er her naturlige og tilfældigt til rådighed i form af kropslig styrke, snedighed, hurtighed osv. Med disse tilfældige midler søger den ene at svække den anden. Det drejer sig om at tilintetgøre den anden for at kunne opretholde sin egen eksistens. Elias kalder denne model en $\mathrm{i}$ rum og tid firdimensional forvikling.

»Samtidig g $\phi r$ dette før-spil, denne model for den uregulerede relation, opmorksom på, at enhver relation mellem mennesker er en proces ... Også begrebet forfletning peger på denne proceskarakter. Og selv om det ved denne tidsligt forlobende forfletning af handlinger fra begge sider drejer sig om en unormeret forfletning, besidder denne proces alligevel en struktur, der er tilgangelig for analysen ${ }^{30}{ }^{30}$

\section{Modeller over normerede forfletninger}

Jeg vil indledningsvis gøre opmærksom på, at de følgende spillemodeller er et tankeeksperiment, der skal tjene som forklaringsmodel og vise a) karakteren i interdependente menneskers relationer, b) i hvilken grad menneskelige forfletninger forandrer sig, når magttyngder fordeler sig, og vigtigst c) gøre de transformationer forståelige, der opstår i mellemmenneskelige relationer, når uligheden i magtfordelingen mindskes.

\section{Model 1 A-to-personers-spil}

Vi må forestille os et spil mellem to personer, hvor den ene spiller A, er den anden spiller B meget overlegen i spillestyrke. A kan i vid udstrækning bestemme over B's træk, hans taktik, adfærd osv. Men A's spillestyrke er ikke ubegrænset. B har også en vis magt over A - var det ikke sådan, kunne der ikke være tale om et spil. Begge vil på en eller anden vis øve indflydelse på den andens adfærd. A kan selvfølgelig i høj grad bestemme spilleforløbet - spilleprocessen som relationsproces - og dermed også spillets resultat.

Her må vi kalkulere med to momenter: a) indflydelse på spillet og b) på spillets forl $\phi b$. Elias pointerer, at det er vigtigt at 
begribe dette på følgende måde, hvis man skal have fuldt udbytte af modellen:

»Men muligheden for at skelne mellem indflydelsen på spillerne og indflydelsen på spillet betyder ikke, at man kan forestille sig spillere og spil som eksisterende hver for sig ${ }^{31}$

\section{Model 1 A's anvendelighed}

I model 1 A bliver spillet stort set struktureret ud fra én persons hensigter. Derfor kan spillets forløb forklares på baggrund af ét individs planer og hensigter. Elias gør opmærksom på, at hvis man tror, at denne model kan forklare samfundsrelationer, befinder man sig på samme niveau som de såkaldte interaktionsteorier.

»Den bringer samtidig mindelser om en velkendt teoretisk samfundsmodel, der udgår fra interaktionen mellem to individer, der if $\phi$ rste omgang er uafhongige af hinanden - fra interaktionen mellem »ego« og »alter «« ${ }^{32}$

En sådan forestilling betyder også, at modellen ikke er tænkt igennem. De skitserede problemer vedrørende »naturen« af menneskenes interdependens, og hvad dertil hører af magtbalancer osv., bliver tilsløret i de såkaldte aktionsteorier. De tildækker et meget centralt problem for sociologien, nemlig at der bag ved enhver interaktion gemmer sig en ikke-gennemskuet menneskelig interdependens. Modellen egner sig ikke til at forstå samfundsmæssige konstellationer, men kan sige noget om relationer af arten specialist/ikke-specialist, slaveholder/slave osv.

\section{Model 1 B-to-personers-spil}

Differencen i den relative spillestyrke imellem A og B er formindsket. Her skifter spilleforløbet karakter. Den enkelte spiller er ikke længere i stand til at præge spillets forløb ud fra sine hensigter og planer.

»Jo mere forskellen i spillestyrke mellem A og $B$ indsnavres, jo mindre står det $i$ en af de to spilleres magt at tvinge den anden til en bestemt spilleadfard. Desto mindre er en af spillerne $i$ stand til at kontrollere spilfigurationen, og desto mindre er den alene afhongig af den ene eller den anden spillers hensigter og de planer, de hver for sig har lagt. Omvendt er den samlede spillestrategi og hver af de to spilleres traek så meget desto mere afhoengig af den skiftende spilfiguration, af spilleprocessen; så meget desto mere opnår spillet karakter af en social proces og fjerner sig fra den blotte fuldbyrdelse af en individuel plan; og i så meget desto højere grad resulterer med andre ord to enkeltmenneskers forfletning af trak $i$ en spilleproces, som ingen af spillerne har planlagt ${ }^{33}$

\section{Model 2 A-flerpersoners- spil på ét plan}

Hermed menes et spil mellem A og spillerne B, C og D under følgende betingelser. A er hver af de andre spillere meget overlegen. Han spiller enkeltvis med henholdsvis B,C og D. Det eneste fællesskab B,C og D har med hinanden er, at de alle spiller mod A. Vi har at gøre med en serie af to-personers-spil, hvor hvert enkelt spil har sin egen magtbalance og udvikling; mellem spillerne er der som sådan ingen direkte interdependens. A har i hvert spil den største magt 
uden begrænsninger af betydning. Han har i høj grad kontrol over sine modspillere og spillet som sådan. Magtfordelingen er i hvert enkelt af disse spil entydigt ulige, uelastisk, dvs. temmelig stabil. Det er muligt, at A's styrke over for den enkelte bliver mindre, fordi han må koncentrere sig om flere spil og derfor ikke er i stand til at bruge al sin energi på én modspiller. Begrundelsen er, at en enkelt spillers spændvidde og evne til mange aktive relationer har sine naturlige begrænsninger, selv om han står over for adskilte forhold.

\section{Spil 2 B}

Her forestiller vi os, at A spiller mod gruppen B,C,D samtidig. A spiller mod en gruppe, hvor hver enkelt spiller er betydelig svagere end A. Denne model tillader ifølge Elias »spillerum« med flere mulige konstellationer og magtbalancer. Den simpleste er den, hvor sammenslutningen af spillerne B,C,D fungerer gruppemæssigt gunstigt uden indre spandinger mellem spillerne, dvs. står i samlet front over for A. I dette tilfælde er magtfordelingen mellem A og spillergruppen B,C,D mindre, og A's mulighed for at kontrollere spillefor-

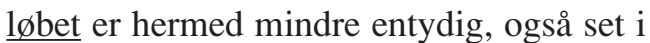
forhold til model 2 A. Gruppedannelsen hos de svagere spillere betyder utvetydigt en formindskelse af A's overlegenhed i spillet. I sammenligning med spil 1 A har såvel kontrol som planlægning af spilleforløbet forandret sig til ugunst for A.

\section{Spil 2 C}

Vi forestiller os, at i dette bipolære spil er A's spillestyrke blevet mindre i forhold til modspillernes. Kontrolchancerne forandrer sig tendentielt som i spil $1 \mathrm{~B}$, forudsat at spillerne B,C,D er forholdsvis enige.

\section{Spil $2 D$}

Her skal man forestille sig, at to grupper af spillere B,C,D,E osv. og U,V,W,X osv. spiller mod hinanden efter regler, der giver begge grupper lige store vinderchancer. Ingen af parterne har mulighed for via træk og modtræk at $\varnothing v e$ afgørende indflydelse på gruppen af modspillere. I dette tilfælde er det hverken muligt for en enkelt spiller eller gruppe at komme til at bestemme spilleprocessen. Her indgår hver enkelt spillers beslutninger, træk for træk, i en forfletning af en vis orden. Denne orden kan forklares ud fra de særlige lovmæssigheder, som udspringer af denne forfletning (figuration). Omtalte teoretiske modeludvikling skal forklare, hvorledes formationsagtige udviklinger forløber. Det er processens særlige dynamik - set fra oven, med afstand til sig selv og sine egne træk - som det er nødvendigt at begribe for at kunne se sig selv som et interdependent individ, der indgår i en formation med en særlig orden.

»Men for at gore det kraves der en vis distancering fra begges positioner, således som disse positioner trader frem, når man betragter hver side for sig. Der er her tale om en orden af en specifik art, dvs. en forfletnings- eller figurationsorden, inden for hvilken ingen handling fra den ene side ene og alene kan forklares som denne sides handling, men kun som en fortsattelse af en foregående forfletning eller en anticipation af den, der forstår, med henblik på en fremtidig forfletning af de handlinger, hver af siderne foretager ${ }^{34}$

Distancering i dens såvel psyko- og sociogenetiske som vidensakkumulerende aspekt er et meget vigtigt problem, som Norbert Elias behandler udførligt i sine 
skrifter om videnssociologi, heriblandt Engagement und Distanzierung, Die Gesellschaften der Individuen og Über die Zeit. ${ }^{35}$

\section{Flerpersoners-spil på forskellige planer}

Ved et flerpersoners-spil skal man forestille sig et spil, hvor deltagerantallet er stadig stigende. Hermed etableres et tryk over for den enkelte spiller og grupperingen som sådan, der giver anledning til en overvejelse om at ændre den indre organisation. Den enkelte spiller må vente stadig længere tid, inden han får mulighed for at foretage et træk. Det bliver samtidig stadig sværere for den enkelte at få et overblik over såvel spilleforløbet som spillefigurationen, der er i stadig forandring. Har den enkelte spiller ikke et billede af spillefigurationen, taber han orienteringen over spilleforløbet. Når overblikket er tabt, har spillet som sådan sprængt de rammer, som spillerne forsøgte at opstille.

$»$ Figurationen af interdependente spillere og det spil, som de spiller med hinanden, er bestemmende kontekst for den enkeltes trcek ${ }^{36}{ }^{36}$

Spilleren må være i stand til at danne sig et billede af den figuration, hvori han indgår, for overhovedet at kunne vurdere, hvilke trak der giver ham de bedste vinderchancer, og hvilke der giver ham den største sikkerhed over for modspillerens angreb. Den enkelte spiller må være i stand til at overskue hele figurationen, som han selv er en del af, for at kunne foretage rimelige spilletræk. Men som Elias gør opmærksom på, er den enkeltes spændvidde og overblik i en interdependens begrænset. Ved komplekse interdependensfigurer kan et enkelt menne- ske ikke orientere sig og planlægge personlige strategier over mange spilletræk. Når tallet af interdependente spillere vokser, begynder spillet for den enkelte at bevæge sig i stadig mere uoverskuelige retninger. Selv for en meget stærk spiller bliver spilleforløbet mere og mere ukontrollabelt.

$»$ Forfletningen af flere og flere spillere fungerer altså $i$ stigende grad - set fra den enkelte spillers position - som om den besidder et eget liv «. ${ }^{37}$

Et spil, som stadig flere mennesker spiller med hinanden, får en fremmed, genstandsagtig karakter over sig, når spillet som sådan bliver uoverskueligt. Både spillet og den enkeltes billede, erfaringer og opfattelser af spillet ændrer sig i en bestemt retning. I det $\varnothing$ jeblik, hvor spillet ikke kan kontrolleres, kommer det til at fremtræde som en fremmed magt.

"De forandrer sig i funktionel interdependens som to uadskillelige dimensioner af den samme proces. Man kan betragte dem adskilt, men ikke som adskilte. $\ll^{38}$

Processen selvstændiggør sig over for den enkelte som en anonymitet med sit eget liv og giver ham anledning til at tro, at han som »subjekt« står over for et »objekt «. Konsekvensen er, at når han begrebsligt vil udtrykke sine refleksioner over den sammenhæng, han indgår i, bliver det med en terminologi, der har et tingsligt prog. Fremmedmagten synes at installere forskellige tilstande eller egenskaber i individerne. Nogle af Foucaults bøger og selve hans skriveform, mener jeg, udtrykker og ligger under for denne mystifikation. Den blokerer for bevægelsen og dynamikken i institutionen selv. 
Vi står altså i en situation, hvor en desorientering udvikles i takt med spillets uoverskuelighed, og spillet kommer til at fungere dårligere og dårligere. Problemet er da: Hvorledes får vi etableret kategorier og sproglige midler og modeller, der hjælper os ud over desorienteringen og den opfattelse, at vi står over for et fremmed »objekt $\ll$.

I spilleforløbet, hvor desorienteringen bliver stadig mere markant, og selve spilleforløbet fungerer dårligere og dårligere, kommer det for spillerne til at føles som et pres, og ønsket om en omorganisering melder sig.

Elias nævner tre forskellige omorganiseringsmuligheder. Det $\emptyset$ gede antal spillere kan føre til en desintegration, hvor der foregår en opsplitning i flere grupper. De splittede eller nydannede grupper fjerner sig imidlertid på forskellig vis fra hinanden. I det ene tilfælde spiller hver gruppe helt uafhængigt af de andre. I det andet opbygger man en ny figuration bestående af mindre grupper, der spiller autonomt, mens spillerne forbliver interdependente, idet alle spillere samtidig optræder som rivaler i kampen om fælles eftertragtede muligheder. I det tredje tilfælde kan spillerne forblive integreret og overgår til en figuration af højere kompleksitet; ud af en en-etagesgruppe kan opstå en to-etages-gruppe.

\section{To-etages-spillemodel: Oligarkisk type}

Her gør følgende sig gældende:

»Alle spillere forbliver interdependente. Men de spiller ikke langere direkte med hinanden. Denne funktion bliver overtaget af sarlige funktionarer for spilkoordination - reprasentanter, delegerede, ledere, regeringer, fyrstehoffer, monopoler osv. De danner indbyrdes en anden og mindre gruppe, der så at sige befinder sig på anden etage ${ }^{39}$

Denne elitegruppe er mere eller mindre forbundet til spillerne på 1. etage. Uden en masse af spillere, der indgår som 1. etage, er det ikke muligt at etablere en 2. etage, men måden, de er bundet til hinanden på, og måden, funktionerne er opdelt og sætter sig igennem på, adskiller sig radikalt fra de i ovennævnte modeller angivne. Magtchancerne er nu fundamentalt anderledes fordelt. $\mathrm{Nu}$ betyder det virkelig meget, hvilken figuration og etage, man er en del af. Fordelingen af magttyngderne imellem menneskene på 1.og 2. etage kan nu være meget forskellige. Magtdifferentialet imellem spillerne på 1. og 2. etage kan være overordentlig stor til fordel for sidstnævnte - eller den kan være overordentlig lille. Den kan også blive mindre og mindre.

\section{Eksempler på forskellige magtkonstellationer mellem 1. og 2. etage}

I første tilfælde forestiller vi os, at magtdifferencen mellem 1. og 2. etage er meget stor, kun spillere, der tilhører gruppen på 2 . etage, har direkte indflydelse på spillets forløb: »De monopoliserer adgangen til spillet. $\ll^{40}$

Hver af spillerne på 2. etage befinder sig i en virkekreds i stil med den, vi kunne betragte i flerpersoners-modellen (hvor spillerne spillede på samme plan). Alle deltagende spillere er i stand til at danne sig et billede af spillefigurationen og spilleforløbet. Den enkelte spiller er i stand til at planlægge og udtænke strategier og der- 
med gribe direkte ind i det bevægelige forløb, som spillefigurationen udgør. Han kan endvidere påvirke figurationen inden for gruppen selv (danne alliancer, overbevise den ene eller den anden om sin strategis rigtighed og kvalitet), og dermed indirekte råde over flere taktikmuligheder. Dermed er den omtalte spiller bedre i stand til at beskytte sig over for andre spilleres angreb. Ved at være relativt aktiv kan han blive meget betydningsfuld for spilleprocessens forl $\phi$.

En sådan spiller kan leve med den forestilling, at han har et klart overblik over spilleforløbet. Et eksempel på en sådan person - hvis materiale Elias dog har benyttet på en helt anden måde, end ophavsmanden havde drømt om - er den berømte memoireskriver Saint-Simon. Hans optegnelser er et af udgangspunkterne for Elias' banebrydende analyse i Die höfische Gesellschaft, nærmere betegnet den udformning, dette samfund fik i Ludvig den 14.'s regeringstid. Saint-Simon var et menneske, der levede i en førborgerlig magtelite og var selv overbevist om, at han til bunds forstod de skrevne og uskrevne love ved hoffet. Elias viser, at en sådan persons overbevisning om fuldstændigt at være i stand til at gennemskue sine omgivelser er overdreven, falsk.

»Forestillingen om spillets basale gennemsigtighed er aldrig fuldstandigt $i$ overensstemmelse med virkeligheden. To-etages figurationer - for slet ikke at tale om tre-, fire- og fem-etages figurationer, hvilke for overskuelighedens skyld her er ladt ude af betragtning - er alt for komplicerede konstruktioner til, at deres struktur-og udviklingsretning kan gøres gennemskuelig uden indgående videnskabelig unders $\phi$ gelse ${ }^{41}$
På et tidspunkt bliver det nødvendigt at undersøge organisationsenheder, der har nået en vis kompleksitet. Men den distanceringsevne, der samfundsmæssigt var akkumuleret under Ludvig den 14. og i det samfund, hvor Saint-Simon skrev, havde ikke nået et sådant niveau, at man kunne se sig selv som del af en figur, hvor særlige sociale lovmæssigheder gennemtrænger de bindende normer.

$\gg$ Men til sådanne undersøgelser kommer det først på et samfundsmaessigt udviklingstrin, hvor menneskene er blevet bevidst om deres ikke-viden - altså den relative uigennemskuelighed af det spilleforl $\phi b$, som deres egne trak forholder sig til - og om muligheden for at begranse deres ikke-viden gennem systematisk forskning. Dette er inden for rammerne af dynastisk-aristokratisk samfund, som fungerer $i$ overensstemmelse med en oligarkisk to-etagesmodel, endnu ikke eller kun i meget begranset omfang muligt. Her bliver det spil, som gruppen på 2. etage spiller, endnu ikke anskuet som spilleproces, men kun som en ophobning af enkeltpersoners handlinger ${ }^{42}$

En anden begrænsning i disse spilleres evne til at gennemskue spilleprocessen og dermed give en fyldestgørende forklaring på forløbet skyldes, at ingen spiller i en toetages-spilformation, ligegyldig hvor stærk hans spillestyrke måtte være, tilnærmelsesvis vil være i stand til at påvirke spilleprocessen i samme grad som f.eks. spiller A i model $1 \mathrm{~A}$.

»Selv $i$ et spil med kun to planer besidder figurationen af spillere og spil allerede en grad af kompleksitet, der ikke gør det muligt for noget enkelt individ at 
styre spillet efter egne målsatninger og $\phi n s k e r i$ kraft af sin egen overlegenhed. Individet gør på en og samme tid sine trak uden for og inden for et netvark of interdependente spillere, $i$ hvilket der findes alliancer og modstandere, samarbejde og rivalisering på forskellige etager. ${ }^{43}$

Man kan i et to-etages-spil betragte tre til fire forskellige magtbalancer, der alle som hjul $i$ en gearkasse griber ind $i$ hinanden og forbinder modstandere og venner på det ene plan med fjender og allierede på det andet plan. De magtbalancer, der kan iagttages inden for figurationen, kan fordele sig således: Den første magtbalance udspiller sig mellem spillerne på $ø$ verste etage. Den anden magtbalance eksisterer mellem spillerne på $\emptyset$ verste og underste etage. Den tredje magtbalance danner sig mellem spillerne i den nederste etage og en eventuel fjerde magtbalance inden for hver af grupperne. Elias nævner, at spillemodeller, der kunne omfatte spil, hvor der var tale om 3, 4 eller 5 etager, ville være tilsvarende komplicerede og fortsætter: »Disse ville $i$ realiteten passe bedre på størstedelen af de nuvarende samfund. " ${ }^{44}$

Det er typisk for en to-etages-spillemodel af den oligarkiske type, at magtbalancen til fordel for den $\emptyset$ verste etage er meget stor. Spillets karakter bliver herved kendetegnet ved stabilitet og manglende elasticitet. Den forholdsvis lille gruppe spillere på det $\emptyset$ verste plan er forholdsvis overlegne i forhold til den store masse af spillere, der befinder sig på det nederste plan.

Alligevel betyder interdependensen mellem de to etager, at der sker en indsnævring (begrænsning) i de magtchancer, spillerne på øverste etage råder over. Selv spillere, der på øverste plan råder over meget stor spillestyrke, har mindre spillerum og mindre kontrol over spilleforløbet end f.eks. spiller A i model 2 B. Endvidere er hans kontrol over spillet betydelig mindre end den, som spiller A i spil 1 A besad.

Selv om den oligarkiske model er forholdsvis rigid og stabil, er det alligevel af betydning, hvorledes de 3-4 interdependente magtbalancer udvikler sig. Det er vigtigt, hvordan spillerne i underste etage forholder sig. Sker det, at spillere på øverste og underste etage enes om at bekæmpe den stærke spiller A i øverste etage, da er dennes chancer for at påtvinge de andre hans strategi meget ringe. Magttyngden, balancerne og chancerne skifter til de svagere spilleres fordel i det $\varnothing$ jeblik, hvor de kan enes.

Hvis derimod spillegrupperne på øverste plan er forholdsmæssig jævnbyrdige, og de indbyrdes strides og derved holder hinanden underbundet, uden at nogen enkelt spiller er i stand til at foretage det afgørende træk, da har en enkelt spiller A, der på et højt niveau står uden for denne spillergruppe, meget store chancer for at kunne styre spilleforløbet.

»Hans spillestyrke beror i dette tilfalde på den forståelse og behoendighed, hvormed han formair at gribe de chancer, der frembyder sig $i$ kraft af magtforholdenes aktuelle konstellation, og $i$ hvilket omfang han er $i$ stand til at anlagge sin strategi herefter. Uden A forstorkes de lavere placerede gruppers spillestyrke på grund af rivaliseringen mellem grupperne i $\emptyset$ verste etage ${ }^{45}$

\section{To-etages-spillemodel: Simpel demokratiseringstype}

Ved en to-etages-spillemodel af demokratiseringstypen forstås en spillemodel, hvor spillerne i den underste etages spillestyrke 
vokser langsomt, men kontinuerligt i forhold til spillerne i den $\emptyset v e r s t e$ etage. Når magtdifferencen mellem spillegrupperne på de to planer forringes hen imod en formindskelse af uligheden, da bliver magtbalancen mere mobil og elastisk. "Den har $i$ højere grad tendens til fluktuationer $i$ den ene eller den anden retning. " ${ }^{46}$

Den stærkeste spiller A på øverste plan kan - som tidligere - demonstrere sin overlegenhed over for spillerne på det $\emptyset$ verste plan. Men idet spillerne i den nederste etage kommer i besiddelse af større magtchancer, står han i en spillesituation (position), der er af en mere kompliceret figurativ interdependent art end den spiller, A befandt sig i i den foregående model $3 \mathrm{~A}$. I den ovenfor beskrevne model har spillerne $\mathrm{i}$ den nederste etage allerede en ikke ubetydelig indflydelse på spilleforløbet; men det er en indflydelse, der overvejende er af indirekte karakter. Den øver dermed så godt som ingen direkte effekt på gruppen på 2. etage.

Elias mener, at grunden til, at spillerne på nederste etage kun har en indirekte indflydelse på spillet, er, at der ofte mangler en organisering.

»Til de manifeste tegn på dens latente styrke horer spillerne på den hфjere etages evige vagtsomhed og det tatte net af forholdsregler, der tjener til at holde den under kontrol. Disse forstarkes ofte, nair dens potentielle styrke $\phi g e s$. Dog er den afhongighedstvang, som binder spillerne på det højere plan til spillerne på det lavere, langt mindre synlig. De forstnovntes overlegenhed er endnu så overvaldende stor, at spillerne på det højere plan meget ofte er tilbøjelige til at tro, at de $i$ forhold til spillerne på de lavere planer er absolut frie til at gфre, hvad der passer dem. De føler sig kun bundet og reguleret ved deres interdependens med spillerne $i$ deres egen gruppe og af den indbyrdes magtbalance ${ }^{47}$

Først i det øjeblik, hvor magtforskellen mellem de to planer yderligere formindskes og den direkte afhængighed af spillerne på den nederste etage bliver iøjnefaldende, træder disse frem som modspillere $\mathrm{i}$ bevidstheden på spillerne på det øverste plan. Jo mere magtdifferencen formindskes, desto mere synlig bliver deres tilstedeværelse.

Når magtdifferencen bliver yderligere formindsket, forandres på et tidspunkt karakteren af spillernes funktion og de funktionssammenhænge, som spillerne på $\emptyset$ verste etage indgår i. Sålænge magtdifferencen er meget stor, fremtræder det for menneskene på den øverste etage, som om spillet og også spillerne i den nederste etage er der »for sig selv«. Med forskubningen af magttyngderne ændrer dette forhold sig mere og mere, og det kommer til at se ud, som om alle deltagere, også dem på $\emptyset$ verste plan, er der for spillerne i den nederste etages skyld.

»Lidt efter lidt bliver de forste i realiteten åbent og utvetydigt funktionorer, talsmand, reprasentanter for den ene eller den anden gruppe på det lavere plan ${ }^{48}$

Samtidig med at denne proces foregår, bliver spillet for alle deltagerne mere kompliceret, end det var tilfældet i spil 3 A. Den enkelte spillers strategi i relation til spilleren $i$ den nederste etage bliver lige så vigtig som hans relation til spilleren $i$ den $\phi v e r s t e$ etage. Spilleren i den $\emptyset$ verste etage må nu medregne spillerne i den nederste etage $\mathrm{i}$ sin strategi som et vigtigt aspekt $\mathrm{i}$ spilleprocessen. 
Den ændrede form for interdependens, som spillerne involveres $i$, betyder, at den enkelte spiller i højere grad bliver nødt til at beherske sine umiddelbare impulser og $\mathrm{i}$ højere grad må overveje sine handlinger. Når magtfordelingen ændres, og uligheden i magttyngderne formindskes, sker der samtidig en udvikling af en mere kompliceret og nuanceret social adfærd hos den enkelte spiller.

»Den samlede figuration, som disse sammenvavede spil udgфr, differentierer sig kendeligt og bliver ofte uoverskuelig for selv den mest begavede spiller, således at det bliver stadig vanskeligere på passende måde at beslutte de noeste traek ${ }^{49}$

I forbindelse med udligningen af magtdifferencen mellem 1.og 2. etage sker der her - til forskel fra oligarki-modellen - en meget kraftigere diffusion af magtchancerne. Under visse omstændigheder kan det alligevel forekomme, at en enkelt gruppe, på trods af at magtchancebetingelserne er mere lige, kan komme $\mathrm{i}$ besiddelse af forholdsvis store magtchancer. Sådanne »pludseligt« opståede magtgrupper har for det meste en kort levetid - de opstår for det meste i forbindelse med kriser. En sådan »tilfældigt« opstået magtgruppe bliver sjældent en befæstet magtenhed i stil med den, vi har diskuteret under 3 A. Den her diskuterede model beskriver med hensyn til magtkonstellationer, balancer og tyngder en figuration af en anden strukturel sammensætning end model $3 \mathrm{~A}$, idet selve forfletningen har en anden kompleksitet, interdependenslængde, koncentration og dermed en egendynamik af en anden orden og kvalitet end den, vi stod over for i de tidligere beskrevne modeller. ${ }^{50}$ Herved bliver det også mere tydeligt, at det er spilleforlфbet, der grundet den særlige forflet- ningsorden i høj grad kommer til at strukturere den enkelte spillers træk. Den enkelte spillers forestilling om, hvad der sker omkring ham, skifter karakter. Spilleerfaringer kommer nu i udpræget grad til at $\emptyset$ ve indflydelse på hans sprog og den form, hans tankemønstre etableres i og udfolder sig i den samlede proces' fortsatte forløb.

»Spillernes forestillinger om deres spilderes »ideer«, de intellektuelle og sproglige midler, med hvilke de fors $\phi$ ger at forarbejde og bemestre deres spilleerfaringer, forandrer sig tilsvarende. I stedet for alene at fore spilleforl $\phi$ bet tilbage til enkelte menneskers sarlige trak, styrkes langsomt tendensen til at udvikle upersonlige begreber til tankemassig forarbejdning af spilleerfaringerne. Disse begreber vagter $i$ hojere grad spilleprocessens relative autonomi end de enkelte spilleres hensigter. ${ }^{51}$

Det er den fremmedgørelseseffekt, som komplicerede organisationsstrukturer og samfundsenheder udøver på vores bevidsthed, der gør det nødvendigt i højere grad end tidligere at forsøge at gennemtrænge disse med modeller og orienteringsmidler, der kan optrevle de dynamikker og særlige lovmæssigheder, som udspiller sig i sådanne figurationer. Vi må ikke lade os blokere af de komplicerede enheder, som er processens udviklingsform, og via et statisk sprog udvikle kommunikationsmidler, der er hoemmende for forstålsen af den demokratiserings-og samfundsmassiggфrelsesproces, som ligger implicit i selve forl $\phi$ bet. Problemet vil blive diskuteret nærmere nedenfor, foreløbig skal blot følgende fastslås:

»Men denne udarbejdelse af kommunikerbare tankeformer, som modsvarer den stigende bevidsthed om spillefor- 
løbets - i første omgang for spilleren selv - ukontrollerbare karakter, er en langsom og mojsommelig proces. De metaforer, man betjener sig af, svinger hele tiden frem og tilbage mellem den forestilling, at spilleforldbet lader sig reducere til de enkelte spilleres handlinger, og den forestilling, at det har en overpersonlig karakter. Det er langt hen $i$ spillet overordentlig vanskeligt for spillerne at gore sig klart, at umuligheden af at kontrollere spillet for deres eget vedkommende, hvilket let får spilleforldbet til at fremtrade som en art "overperson", udspringer af deres gensidige afhoengighed og det forhold, at de er henvist til hinanden. $O g$ af de i denne forfletning indeholdte spandinger og konflikter.$^{52}$

Man kan kun forstå, hvordan spilleforløbet har magt over spillerens adfærd, tænken og handlen, når spiller og spilleforl $\varnothing b$ analyseres ud fra den særlige interdependens og processuelle struktur, som spilleren indgår i og er en del af. Hermed bliver den tvang, menneskene udøver over hinanden, transparent. Man kan ikke forstå en spiller »for sig «, men kun ud fra spilleforløbet i dets helhed.

»Modellen viser temmelig klart, hvilke omstcendigheder der er udløsende for den tvang, som deres interdependens som spillere фver på dem som individer, der er bundet til hinanden på denne måde. Det afgørende er deres relations sarlige natur, den sarlige karakter, som deres interdependens som spillere antager. Også $i$ dette tilfalde er magt en strukturejendommelighed ved en relation ${ }{ }^{33}$

Samtidig viser det sig, at den enkelte kommer til at stå over for den kendsgerning, at det ikke længere er muligt at henføre den tvang, som implicit ligger i forfletningsdynamikken, til én person eller gruppe, der udøver den unilaterale magt over alle andre.

Når demokratiseringsprocessen bl.a. giver sig udtryk $i$, at magtdifferencen bliver mindre, og at den tvang, menneskene udøver over hinanden, bliver så differentieret, kompliceret og kaotisk, at mulighederne for at kontrollere det samlede spilleforløb bliver mindre, så er der flere faktorer i denne proces, der påkalder sig opmærksomhed. En af disse er de fremmedgørelseseffekter, der følger i kølvandet på demokratiseringsprocessen.

Med Elias' modeller står vi med et redskab, der er egnet til at gennemskue en særlig art af fremmedgørelseseffekter. Som Elias gør opmærksom på, sætter de fremmedgørelsesformer, som hersker i det moderne samfund, sig helt konkret igennem i vores sprog og tankemønstre, ja helt ind i vores muligheder for at anvende sproget som adækvat orienteringsmiddel.

»Vores hidtidige tankemåde og sprogbrug фver et vist tryk på os i retning af at forklare alle sammenhoenge udialektisk som kader af årsager af virkninger. Denne forklaringsmåde suppleres af den lige så reduktionistiske forlaggelse af årsagen til handlinger og hensigter til en ophavsmand, der forstås som person. Denne type forståelse er historisk celdre, og forst lidt efter lidt $i$ lobet af menneskehedens historie vinder en forklaringsmåde frem, der henviser til en upersonlig årsag. Når man står over for komplekse forfletningsfanomener, søger man sadvanligvis også at forklare disse ved hjcelp af kategorier og billeder, der peger mod serier af årsager og virkninger. Blot forestiller man sig $i$ sådanne tilfalde som regel, at det er tilstrakke- 
ligt at anfore et helt bundt af korte kader af denne art som forklaring. I stedet for en årsag eller en ophavsmand forklarer man da det, som skal forklares, ved et konglomerat bestående af 5, 10 eller måske endog 100 »faktorer«, "variabler", eller hvad man ellers måtte kalde dem. Hvis man forsøger sig med denne forklaringstype på en spillers tolvte traek i et spil med to personer, der befinder sig på et plan, hvor spillerne er lige starke, vil man hurtigt erfare, hvor langt den rakker ${ }^{54}$

I stedet for at lade de fremmedgørelseseffekter, der følger med demokratiseringsprocessen, overskygge demokratiseringsmulighederne, må vi undersøge processtrukturerne som det, de er, nemlig samfundsmæssige problemområder. Selv om dette kræver selvdistance og evne til at gennemleve og bearbejde umiddelbare frustrationer.

»Med tiden bliver det noget lettere at forstå, at netop når magtforskellen mellem interdependente individer og grupper formindskes, bliver muligheden for at kontrollere det samlede spilleforl $\phi b$ ligeledes mindre, såvel for de deltagende spillere som enkeltindivider som for spillerne som grupper. Stigende distancering fra ens egen placering $i$ en forfletning og stigende indsigt $i$ spilleforlobets struktur og dynamik kan da atter фge kontrolchancerne. Sociologiens relative autonomi i forhold til andre videnskaber, der beskaftiger sig med de enkelte mennesker, såsom fysiologi og psykologi, beror da i sidste instans på den relative autonomi af de processtrukturer, der udspringer af mange menneskers interdependens, samt forfletningen af deres handlinger, anskuet i forhold til den enkelte handlende.$^{55}$
Med figurationsanalyser er det muligt at optrævle og få indsigt i de strukturejendommeligheder, som kendetegner »Verflechtungsprozessen «. Såvel processerne som magtforskydningerne er analyserbare. De afhangighedsrelationer, som menneskene står i, og de funktioner, de har i forhold til hinanden, træder frem på baggrund af de herskende magtbalancer. Spillemodellerne er derfor egnede til at undersøge magtrelationers konkrete struktur inden for institutioner. Det er herigennem muligt at afdække disses funktion som socialisationsagenturer og belyse dem som materialiseringer af menneskelige relationer.

»Da ser man samtidig også, hvor snover en sammenhang der er mellem de funktioner, som interdependente mennesker har i forhold til hinanden, og magtforholdet mellem dem. Om det drejer sig om funktioner mellem arbejdere og arbejdsgivere $i$ industrivirksomheder, funktioner mellem to grupper inden for en stamme, der ligger i en institutionaliseret fejde, funktioner som beherskede grupper udøver, funktioner i forholdet mellem agtemand og agtehustru, forceldre og børn - altid er de anledning til styrkeprøver, der sadvanligvis relaterer sig til problemer som: Hvem behøver hvem mest? Hvilken funktion ud $\phi v e r$ den ene i forhold til den anden, hvis afhoengighed af den anden er størst? Hvem har større magtchancer og kan følgelig $i$ hojere grad styre den anden, hvem kan formindske den andens funktioner eller helt berøve ham dem? «56

Hensigten med ovennævnte modeller og indsigter er således at gøre opmærksom på, at »Verflechtungsprozessen « er processer, der, selv om de forløber som ikke planlagte processer i tid og rum, er tilgængelige 
for analyser, der viser strukturen i de figurationer, som interdependente mennesker danner med hinanden. Det er ikke nødvendigt at lade sig overrumple og mystificere i en sådan grad, at disse instanser eller institutioner kommer til at fremtræde, som om de $»$ besad et eget liv.$^{57}$

\section{Til forståelse af sociale bindingers betydning for menneskers interdependens}

$\gg$ Med begrebet figuration retter man opmarksomheden på menneskenes interdependenser. Spфrgsmålet er, hvad der egentlig binder mennesker sammen i figurationer $« .{ }^{58}$

For at forstå forfletningssammenhængene og de bindinger, som disse medfører, er det vigtigt at redegøre for begrebet åben og bunden valens. Dermed anskueliggøres affektive bindingers eksistens og betydning i en figuration.

Normer er ifølge Norbert Elias ikke biologisk fikseret. Menneskene er nemlig i den situation, at de i modsætning til dyrene kan danne varierende, foranderlige samfund, uden at en udvikling eller omformning af deres biologiske grundlag er nødvendig. Men samtidig er mennesket aldrig noget, der kan stilles uden for en samfundsmassig udviklingsproces.$^{59}$ Udviklingen af menneskelige behov og tilfredsstillelsesformer er ikke blot noget, der udgår fra individets egen krop, men er i høj grad afhængig af den figur af interdependente mennesker, som individet på et givet historisk tidspunkt indgår i; dvs. af såvel det psyko- som sociogenetiske udviklingsniveau. ${ }^{60}$

Elias gør opmærksom på, at karakteren af menneskers afhængighed af hinanden på forskellige samfundsmæssige udviklingsniveauer på ingen måde er den samme. Et stort antal iagttagelser peger på, at en hel skala af behov kræver en tilfredsstillelse, som rækker ud over den seksuelle.

»Når man taler om seksuelle bindinger, så rykker man et meget centralt, men alligevel relativt begranset og forbigående aspekt af menneskenes relationer storkt i forgrunden. Det, som karakteriserer menneskelige følelsesbindinger, er muligheden for en affektiv permanens ud over seksualakten og muligheden for meget starke emotionelle bindinger af forskellig art, der ikke har et seksuelt $\operatorname{prceg}{ }^{61}$

Med dette og det følgende citat bliver det indlysende, at Elias med sine figurationsanalyser søger at opbygge et kategoriinventar, der overskrider psykoanalysens, og ikke overfører psykoanalytiske kategorier på fænomener, der ligger uden for dens genstandsområde - hvor deres udsigelseskraft i givet fald ville være betydeligt svækket. Men samtidig indoptager Elias kritisk psykoanalytiske erfaringer og integrerer dem i et selvstændigt opbygget begrebsapparatur.

»Det forekommer mig også, at begrebet "valenser " bedre end begrebet »libido" $i$ dets nuvarende formulering doekker den kendsgerning, at et menneskes emotionelle bindinger normalt har gruppekarakter... Uden tvivl indtager $i$ en sådan valensfigur bindinger af seksueltaffektiv karakter mellem mand og kvinde en central stilling $i$ de udviklede industrisamfund. Dog forekommer, som allerede novnt, vore nuvarende teoretiske begreber at vare noget ensidigt orienteret mod idealet om det agteskabelige 
monogami. Det turde vare mere i overensstemmelse med faktiske iagttagelser at forudscette, at menneskenes affektive impulser i forhold til hinanden og affektive bindinger til hinanden på et givet tidspunkt er mere omfattende og mangfoldige, end de af dette ideal inspirerede modeller lader fremgå ${ }^{62}$

Den udvidelse, som Elias foretager af vor forståelse, har konsekvenser for det menneskebillede, han argumenterer for. Elias vil gøre opmærksom på, at selv om nogle følelsesytringer finder tilfredsstillelse i faste og stabile relationer, er det kendetegnende for mennesker, at de råder over et nuanceret spektrum af potentielle bindinger og afhængighedsmuligheder. Mennesker har mulighed for mange og varierende valensrelationer. Derudover er den enkelte til stadighed i besiddelse af valenser, som ikke er fast forankret. De er frie og umættede (se fig. 2) og søger mod andre mennesker.

»Når man erstatter det menneskebillede, der udtrykkes med »homo clausus", med det »åbne menneske", fremstår forestillingen om de mod andre mennesker rettede affektive valenser som et frugtbart redskab ${ }^{63}$

Med en for stærk vægtning af seksuelle bindinger blokeres for nuanceringen $\mathrm{i}$ de stadig skiftende valensbindinger, hvorved menneskets bevægelse mod andre og nye forbindelser underbetones. Det er selvfølgelig i denne sammenhæng klart, at de mennesker, der er blevet beskadiget i primærsocialisationen, ikke er så bevægelige som mennesker, der er kommet nogenlunde »ubeskadiget « igennem den tidligste barndom. Neurotiske menneskers handlemuligheder må derfor ikke overføres på det teori- eller genstandsfelt, som vi her er i færd med at beskrive; deres blokeringer bør løses på psykoanalytisk vis. I det tilfælde, hvor driftslivet og identiteten hos befolkningen i almindelighed er fikseret og sønderbrudt, da er det et alvorligt samfundsmaessigt problem. Men selv om én, mange eller måske alle til en vis grad er neurotiserede, må vi alligevel se vores socialisationsmuligheder også ud fra valensperspektivet. I modsat fald vil vores samfundsmæssige handlekraft og orienteringsmuligheder til afhjælp af »dagligdagens « mystificerende tvang blive totalt lammet.

Den her behandlede tematik skal hjælpe os til at betragte mellemmenneskelige følelser, bindinger og afhængighedsrelationer som processuale og dynamiske. Valensskæbner er mere dynamiske i deres udvikling end libidoskæbner, hvilke forstås i forhold til ganske bestemte mønstre af subjektive og objektive relationer. Hvis man stopper ved jeg- eller vi-perspektivet, går forståelsen for figurationens dynamiske aspekter tabt. Ved at anskue følelsesbindinger og afhængighedsrelationer ud fra pronomenerne jeg, du, han, hun, vi, I, de, men vel at mærke i deres konkrete, personorienterede betydning, fås en betydelig mere nuanceret og perspektivrig forståelse for mellemmenneskelige anliggender som tæt sammenvævede relationer og funktioner. Der åbnes for en dynamisk, foranderlig opfattelse af valensfigurer, også den enkeltes; dette befordrer en åben og fremtidsorienteret adfærd. Hermed skulle det være muligt at overskride en jeg-orienteret driftsunderbundet bevidsthed, der holder fast ved det stationære, det uforanderlige, det én gang forudbestemte.

»Samtidig ser man ved hjoelp af denne model allerede noget tydeligere, hvor uanvendelige på den menneskelige 
situation alle de tankemåder er, der foregфgler os, at det egentlige »jeg «eller »selv« har bolig et eller andet sted $i$ det enkelte menneskes indre, helt aflukket for andre mennesker, til hvem man siger »du« eller »vi«-om hvem man siger »han« eller »hun«. Erkendelsen af, at folelsen af sig selv som den person, man kalder »jeg ", er ulфseligt forbundet med folelsen af andre mennesker som

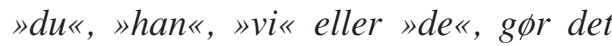
måske lettere til en vis grad at distancere sig fra den forestilling, at man eksisterer som person $i$ sit eget »indre", mens alle andre mennesker optrader som personer »uden for « ${ }^{64}$

\section{Valensbindinger til symboler}

Når figurationer omfatter store og særdeles komplekse enheder som f.eks moderne stater, kan man ikke nøjes med at se følelsesbindinger alene ud fra en personlig synsvinkel. Man kan her iagttage, at bindinger retter sig imod symboler af en anden art og størrelsesorden end de personlige - nemlig nationale kendetegn, samfundsbestemte symboler og affektivt besatte begreber.

Statsdannelsesprocessen og den udformning og sammensætning, som centralmagten får, er af betydning for dannelsen af befolkningens habitus. Den kontinuitet - eller mangel på samme - hvormed statsdannelsesprocessen realiseres, betyder også meget for, hvad jeg vil kalde vi-identiteten $i$ en nationalstat. Statsdannelsesprocessen indgår som et symbol i den enkeltes »vibillede« under identitetsdannelsen. Dette såkaldte vi-ideals dannelsesproces er af en tidsmæssig anden orden - dets stabiliseringsfunktion af en anden tyngde end jegidentitetens.
»Denne forankring af individuelle valenser $i$ sådanne store samfundsmoessige enheder har meget ofte samme intensitet som bindingen til en elsket person. Også $i$ dette tilfaclde bliver det individ, der således er bundet, rystet $i$ sit inderste, når den elskede samfundsenhed bliver $\phi d e-$ lagt, besejret eller taber $i$ vardi eller vardighed. Det er en af de store mangler ved vor tids teoretiske sociologi af den aldre skole, at dens forskningsbestrabelser så godt som altid retter sig mod samfundets »de«-perspektiver og nasten aldrig systematisk og med pracise begrebsmassige redskaber medinddrager også »jeg«- og »vi«-perspektiverne $i$ unders $\phi$ gelsen $« .65$

National identitet er et symbol, der er produceret og har eksisteret over flere hundrede år. Vi må være klar over, at symbolerne er en slags aflejringer, nedslag fra tidligere epoker - tegn for identifikationer og identitet. Disse identifikationstegn er nødvendige for, at man kan leve - og til dem er der knyttet stærkere eller svagere følelser. De er ladet med fortid - »mit Vergangenheit und Gewissen «. ${ }^{66}$

De magtkampe, der har udspillet sig i figurationer, hvis aktører for længst er døde, lever på forskellig vis videre $\mathrm{i}$ de mennesker, der bærer, forsvarer og føler nationalitet. En analyse af procesagtige samfundsmæssige udviklinger af symboler med forskelligt følelsesindhold og betydning giver Elias i sine bøger Über den Prozeß der Zivilisation (Bd.1, 1. kapitel: Zur Soziogenese der Begriffe »Zivilisation" und »Kultur ${ }^{67}$ ) og Studien über die Deutschen. Machtkämpfe und Habitusentwicklung im 19. und 20. Jahrhundert. ${ }^{68}$ 
Figurationsanalyser som

forståelsesgrundlag for

langsigtede samfundsmossige procesforl $\phi b$. Noter til

forholdet mellem sociologi og historie

"Alle de individer, der danner sådanne figurationer med hinanden, er enestående og eksisterer kun denne ene gang. Men figurationen selv kan opretholde sig over mange generationer under relativt ringe og langsomme forandringer. Figurationer, der nosten er identiskesom $i$ det mindste udviser temmelig langsomme forandringer - kan folgelig dannes af nye og andre individer, der skifter forholdsvis hurtigt. Set fra de hurtigt skiftende, de enestående og ikke gentagelige individers position fremtrader de figurationer, mennesker danner indbyrdes, da som fanomener, der gentager sig, som er mere eller mindre uforanderlige $\ll .{ }^{69}$

Til perspektivering af begrebsapparatet i Elias' figurationsmodel fig. 2 og som problematisering af de stillede spørgsmål vedrørende kategorisering af omslagsfelter og socialisationsagenturer vil jeg gøre opmærksom på nogle videre aspekter ved figurationsanalyser. Begreberne omslagsfelt og socialisationsagentur betegner figurationer, interdependente mennesker danner med hinanden og tjener til at bestemme den dynamiske og processuelle tvang, mennesker udøver over hinanden - de funktionelle og affektive afhængigheder, der hersker overalt, hvor mennesker er samlet i grupper.

Socialagenturer findes i utallige afskygninger med forskellig omslagshastighed og intensitet. Disse indgår i kæder og møn- stre, men hver figuration har sin egen historicitet og sarlige strukturejendommeligheder, som kan eftervises empirisk.

»Disse figurationer er lige så virkelige som de enkelte mennesker, som danner dem. Hvad der i begrebsmassig henseende endnu i dag synes vanskeligt at forstå, er den kendsgerning, at de figurationer, mennesker danner med hinanden, kan have en langsommere forandringstakt end de enkelte mennesker, som danner dem ${ }^{70}{ }^{70}$

Figurationer står eller falder ikke med enkeltpersoners liv og død; navne, normer, skikke, sociale magtkampe, viden og erfaringer fungerer fortsat som akkumulerede sociale læreprocesser. Handle-, tanke- og vidensformer overleveres til de nye generationer, der bliver født ind i figurationerne. Dette er det nødvendigt at være bevidst om, hvis man skal kunne begribe sig selv og andre som historiske væsener. Man kan ikke forstå et individ, en gruppe eller en befolkning uden at kende de figurationsbetingelser, der er medbestemmende for hans/huns/deres handlingsspillerum, adfærd, personlighed, standsetos eller nationalkarakter.

Hertil kommer, at nogle figurationer har større samfundsmæssig, socialisationspolitisk rækkevidde end andre. De såkaldte elitegrupper præger i høj grad de grupper af befolkningen, hvis indflydelse er mindre outsiderne. $^{71}$

\section{Figurationernes langsigtede udvikling forlфber planlфst}

Hele den hidtidige historie er $i$ grunden en kirkegård for menneskers drфmme. ${ }^{72}$ 
Forståelsen for figurationsanalysers dynamik og lovmæssigheder skal animere til at foretage analyser af langsigtede procesforløb. Derved vil det blive klart, at mellemmenneskelige relationer i al for $h ø j$ grad bliver bestemt af kortsigtede interessekampe. Ved ikke at prøve at fremme forståelsen for langsigtede analyser - unders $\emptyset$ gelser af processer, der strækker sig over flere hundrede år - kommer man såvel teoretisk som handlingsstrategisk let til at blive fanget af umiddelbarhedens kompleksitet. Konsekvensen er, at de samfundsmæssige processer kommer til at forløbe ukontrolleret - umiddelbarheden holder alle underbundet, samtidig med at historien sætter sig planløst igennem.

»Kun inden for bestemte grcenser er menneskene $i$ stand til at erkende og kontrollere de figurationer, de danner med hinanden. Inden for en figuration er der ofte store forskelle i magt og indsigt. Endog personer, som inden for en sådan figuration har forholdsmaessig stor magt over de andre, er for det meste magteslфse, når det kommer til kontrollen over figurationen som en helhed. Således er, som f.eks. allerede Marx har vist, kapitalisterne fanget $i$ kapitalismens net; thi de er ude af stand til at styre udviklingen af den figuration, inden for hvilken de indtager så magtfulde og privilegerede positioner . $^{73}$

Elias hævder, at det er nødvendigt på empirisk grundlag at give sig i kast med udvikling af modeller, der rækker ud over, hvad han kalder »zustandsreduzierte « opfattelser og vurderinger af samfundsmæssige fænomener. Teoriens opgave er at give et analyseredskab, der er i stand til at give en forklaring på langsigtede tendenser inden for såvel samfunds- som personlig- hedsstrukturer. Først når man gennemskuer, i hvor høj grad den accentuerede samfundsmæssige forviklingsdynamik bevæger sig mod større og større afhængigheder og stadig mere komplicerede funktionsformer mennesker imellem - først da er man i stand til at begribe den forandring, som sker med det menneskelige habitus.

»Man kan ikke forstå adfordens civilisation og den tilsvarende omformning af den menneskelige bevidstheds- og driftshusholdning uden at forfølge statsdannelsesprocessen og centraliseringen af samfundet $\ll{ }^{74}$

Dermed bliver det klart, hvor plastisk og modellerbart menneskets "psykiske apparat« er. I det øjeblik vi betragter driftsmodelleringen, ikke som omformning af fremmedkontrol til selvkontrol, men som en af betingelserne for et udvidet handlingsspillerum, dvs. erkender potentialerne i de psykiske funktioner, både i deres socio- og psykogenetiske aspekt; da åbnes for en virkelig forståelse for menneskenes samfundsmaessige muligheder.

\section{Om symbolisering - fragmentering og socialisering}

De radikale og komplekse strukturændringer, som sætter sig igennem i oplevelsessamfundet, kommer også til syne i idrætslivet og dets placering i landskaberne, byerne, arkitekturen, teknologien, medierne og moden. Med opløsningen af de traditionelle klassetilhørsforhold, som tidligere i høj grad prægede den enkeltes adfærdskanon og idrætsvalg, er vi i dag vidne til en større fleksibilitet, men også større fragmentering og uoverskuelighed for den enkelte. 
Opdelingen og skellet mellem fin- og populærkultur findes ikke længere. I dag udnytter man de kulturelle tilbud, som forefindes, på tværs af konventionelle køns- og klasseskel. Der er ikke så langt fra fodboldbanen, kunstudstillingerne, cafeerne, Det kongelige Teater, opera og ballet til en tur i Parken eller et andet multifunktionelt stadion, hvor man kan gå til rockkoncert, opera eller fodboldkamp.

Det samme gør sig gældende med fjernsyn og internet, hvor samspillet mellem det lokale og det globale opløser sig i fragmenterede billeder. Eller samles i en bevægelse, der forbinder niveauerne i en forståelse, hvor konkrete kropserfaringer forener sig med et globalt helhedssyn. Vi kan konstatere lige så mange og nye interessefællesskaber inden for idrætslivet som i så mange andre kulturelle institutioner og manifestationer. De lever med hinanden i glidende overgange, som på sigt kan være såvel fragmentariske og flygtige som eksperimenterende og banebrydende.

Der sker udviklinger i de samfundsmæssige livsmønstre, hastige bevægelser, som er vitale set fra den enkeltes indvidualiseringsproces og livsperspektiv. De, der råder over de sanselige, kropslige, intellektuelle og økonomiske potentialer, har udsigt til et liv, hvor mange ønsker og behov kan realiseres, forudsat man forstår nødvendigheden af at orientere sig og koordinere sine valg, så mangfoldigheden knytter an til et større helhedssyn. Og sprænger det dualistiske menneskebillede, hvor statiske begreber og forståelsesformer deler menneskets livsverden i en krop og en sjæl, hvis bevægelser følger de samme lovmæssigheder $\mathrm{i}$ al evighed. Man kan ved at få indsigt $\mathrm{i}$ det situerede og det legemliggjorte overskride en individualitetens tilfældighed, fordi det at kunne er at virkeliggøre en konkret social betydning. Vi bærer de hi- storiske producerede muligheder og interaktionsformer med os. De potentialer og livsudkast, der blev grundlagt i den enkeltes socialisationsproces. Vi kan udnytte arven fra de generationer, som ikke er mere, men som lever videre i den historiske proces. Tiden er i så fald til stede i den kropsfigur, det psykiske og fysiske habitus, der er bindeleddet mellem arvegenetiske forudsætninger og civilisatoriske processer. Den tyske læge, psykoanalytiker og sociologiprofessor Alfred Lorenzer udtrykker det på denne måde i Die Natürlichkeit des Menschen und die Sozialität der Natur:

»For ham (Freud) var de ubevidste impulser aldrig blot omdannet livsenergi. De var meningsfigurer, der altid var nфje scenisk adfardsanvisende. Men modsiger antagelsen af en sådan organisk indskrevet meningsstruktur, der ligger under og forud for kommunikerbare processer, og som er resultat af vekselvirkningen mellem somatisk grundstruktur og indvirkninger fra omverdenen, ikke alle de indsigter, vi har om psykiske lareprocesser på genetisk fastlagt arvegrundlag? Skal vi anfagte den almindelige inddeling $i$ arvegenetisk pragede kropsformer og kropsfunktioner på den ene side og sociale oplevelser på den anden, hvilke lidt efter lidt fylder kropsorganisationen med indhold?

Det skal vi ganske afgjort, og her er vi lige pracis ved det punkt, hvor det Freudske koncept overgår sine samtidige og nutidige videnskabelige modstanderes og havder sig som forarbejde til en socialisationsteori, der for alvor er på niveau med den moderne neurofysiologi. Rent faktisk banes der med neurofysiologiens resultater vej for en bemoerkelsesvardig bekraftelse af Freuds opfattelse. Når neurofysiologien på sit ak- 
tuelle stade arbejder sig frem mod en forståelse af den neurale grundstruktur som et netvark, der hviler på en vekselvirkning mellem spontan og provokeret aktivitet, og denne vekselvirkning igen og igen virker tilbage på generne, så resulterer disse indsigter $i$ antagelsen af en organisk meningsstruktur, som har alle de karakteristika, som Freud tilskrev det ubevidste. Vi står over for oplevelsesfigurer, der er smeltet sammen med kropslige behov og processer, fordi de umiddelbart er nedslag af det allertidligste samspil mellem fotale egenimpulser og omverdenspirringer. Hvad mere er: dette samspil virker tilbage på generne på en sådan måde, at Luciano Meccacci kan tale om, at sethvert individs hjerne [...] adskiller sig fra alle andre individers hjerner " - biografisk-individuelt og med et kulturspecifikt sar$\operatorname{prag} .^{75}$

Vi aner her, at videnskabelige erkendelser og modeller fra flere genstandsfelter st $\varnothing t t e r$ figurations- og processociologiens antagelse, at mennesket kan begribes på flere planer. Det er modeller som er meget komplekse, men som det i fremtiden vil være oplagt at forfølge i en interdisciplinær forskning, der opererer på et højere synteseniveau end både den klassiske erkendelses- og videnskabsteori og den specialiserede bindestregssociologi.

Derfor må de farer, som Gerhard Schulze viser truer den enkeltes orientering, tages alvorligt. Massekulturen manifesterer sig via myriader af tegn i en samfundsudvikling, hvor der i stadig stigende grad foregår en æstetisering af hverdagen. De flygtige sociale mødesteder bliver mere og mere til oplevelses- og handlingsfællesskaber, hvor de vekslende psykofysiske symboliseringsdannelser bliver prægende for de enkeltes identitetsprocesser. Det sker via scenerier og procedurer, der ustandselig lægger op til en subjektiv reception af den massive, men flimrende tegnproduktion $\mathrm{i}$ et samfund, som ikke længere primært er bestemt af en økonomisk, men af en psykofysisk semantik.

Samtidig overtager flere og flere institutioner prægningen af den kollektive individualitet. De gamle institutioner har mistet deres afgørende funktion som hjemsteder for individernes liv. Det er ikke længere i så vid udstrækning familien og klassen, der danner rammen om menneskers indbyrdes relationer. Deres funktion bliver i stigende grad overtaget af løst strukturerede gruppedannelser i det offentlige rum samt af professionel vejledning og rådgivning. En art upersonlig forvaltning kan da bemægtige sig de intime og fortrolige områder af den enkeltes liv.

Som Norbert Elias og Johan Goudsblom viser, har sociologien udviklet sig til en løs ansamling af fragmenter. Dette har medført, at dens genstandsfelter også fremstår som splittede, disparate og uoverskuelige.

En fejlagtig tilgang til oplevelsessamfundet som historisk fænomen kan medføre, at den oplevede og den forklarede virkelighed falder fra hinanden. Og at udviklingen af den sociologiske orientering enten bliver styret af billeder, der fører og forfører, eller baserer sig på sofistikerede begreber, der opererer på så højt et abstraktionsniveau, at de ikke forbinder sig med andet end deres egne spekulative forudsætninger. I så fald har man tabt sensibiliteten over for menneskenes subjektive forankring i de livssammenhænge, som udvikler deres individuelle og kulturelle identitet. De atomiserede problemstillinger og de flygtige billeder tillader ikke at bestemme forhold, der handler om magt og afmagt, 
og udarbejde de mønstre, der synliggør betydningen af magtbalancerne mellem etablerede og outsidere.

Vi må i vores empiriske arbejde forsøge at gøre funktionssammenhængen og strukturen i de mellemmenneskelige relationer transparent som én forudsætning for at gennemskue historisk udviklede symboldannelser. De symboliseringer, som er resultatet af menneskers praksis, er tæt forbundne med magt- og afhængighedsmønstre. Vi kan være med til at bryde mystifikationerne, deres fremmedgørende præg og uigennemskuelighed ved hjælp af de her beskrevne lære- og spillemodeller og vise, at der ikke er tale om rationelle og eviggyldige lovmæssigheder, men om sociale processer, hvor der hersker mere eller mindre labile magtforhold.

Med de proces- og figurationssociologiske modeller råder vi over orienteringsmidler, der kan trænge bag om de flygtige billeder og den tingsliggjorte facade. Også $i$ et større historisk, endog fylogenetisk perspektiv kan de vise, at menneskers psykiske og fysiske habitus er bundet i figurationer og interdependenskæder, som til enhver tid præger sig ind som kropslige og vidensmæssige matricer, der på én gang er hæmmende og nødvendige for livsudfoldelsen. Dette kan både bidrage til forståelsen af de dynamikker, der foregår inden for større samfundsmæssige formationer, og til analysen af dagligdagens bevægelser, således som de bl.a. kommer til udtryk i leg, spil og sport.

De symboliseringsprocesser, som er resultatet af menneskers praksis, kan føres tilbage til konkrete, materielle livsbetingelser og besidder en psykofysisk betydningsstruktur eller semantik. De træder frem i konkrete iscenesættelser og scenarier, hvor menneskers relationer og afhængigheder kommer til syne. Og i den kodeks, der påtrykkes den enkelte via tidsligt og rumligt organiserede regelpåtvingelser og ritualer. Disse forbinder sig ofte med materielle formorganiseringer, heriblandt arkitekturen.

Her gælder stadig:

Jeg vil her knytte an til min artikel Idrat og Arkitektur - krop, sprog og socialisering i Idrætshistorisk Årbog $1997^{76}$, hvor jeg gør mig overvejelser om menneskeskabte symboler og kommunikation af viden ud fra Norbert Elias' bog Symbol Theory. ${ }^{77}$

$\gg$ Menneskene er - om de er sorte, røde, gule eller hvide - medlem af en ensartet art, menneskeslagten, og samtidig er de medlem af forskellige samfund. Her står vi overfor et problem og en udfordring, som er udpraget menneskelig, og som ikke påvirker trakfugle, ulve eller andre dyr, der krydser menneskeskabte granser. For deres livsførelse foregår bag om de symboliseringsprocesser, vi kalder planlagning og kulturel kommunikation. De ligger så at sige fastlagt $i$ deres biologiske forudsatninger.

Menneskene kommunikerer ved hjolp af symboler, som er skabt af mennesker, og er forskellige fra samfund til samfund. De er ikke som ved forskellige dyrearter karakteriseret ved arten, men ved det samfund, som de er vokset op $i$. Det sprog, de skikke og den viden som mennesker dermed er $i$ stand til at akkumulere, bevare og formidle fra den ene generation til den naeste. Den er på den anden side ikke mulig at fiksere genetisk. [Og dog, hvis det sker i en vekselvirkning mellem en naturlig og en social proces, hvor det lykkes at forene og forbinde de biologiske potentialer med en civilisationsbetinget, social virkelighed, S.N.]. Det er en viden, der opstår og tilegnes gennem en lang laereproces $i$ det 
samfund man vokser op i. Desuden er sprogets struktur og betydning determineret af dets sociale funktion og den kulturelle arv og det civilisatoriske mønster, som er karakteristisk for det pågceldende samfund. Menneskene besidder en evne til at kommunikere, men optrader overfor hinanden med meget forskellige sociale og kulturelle forudsatninger. Det betyder, at det biologisk ensartede, arten menneske, står indbyrdes overfor hinanden med en meget h $\phi j$ grad af social mangfoldighed. Det, at vi alle er $i$ stand til at benytte sprog og $\mathrm{ud}$ vikle symboler, betyder, at menneskene på den ene side optrader overfor hinanden som enheder, på den side anden som en helhed af forskelligheder. De sanselige symboliseringsprocesser og sproget kan således tjene til at integrere eller splitte - lukke inde eller ude «. ${ }^{78}$

Norbert Elias' modeller over figurationsanalyser er vigtige, fordi han er den første, der også via sceniske beskrivelser konkret har vist, hvorledes sammenhængen mellem magt og afhængighedsmønstre i de mellemmenneskelige forhold kommer til udtryk, såvel i den enkeltes adfærdskoder som i overgribendede materielle formsprog som f.eks. arkitekturens. Ved hjælp af figurationsanalyser bliver man i stand til at gennemskue, hvordan forholdet mellem materielle iscenesættelser og bevægelsesmønstre i kroppen formes og organiseres. Man ser udefra med en reflekteret distance, hvordan de forskellige individuelle og kollektive symboliseringsprocesser udvikler sig i et interdependent mønster, uden selv som forsker at være direkte involveret i figurationen. Men selv om man har analyseret de magtpolitiske aspekter i menneskenes iscenesættelser og livssammenhænge i et sociologisk perspektiv, må man, hvis man skal forstå, hvorledes disse virker ind på menneskers »subjektive« måde at opleve verden, også bestemme dem i et socialisationsteoretisk perspektiv.

Opgaven er at udvikle orienteringsmidler, der sætter os i stand til at forstå, hvorledes materielle livsbetingelser og dynamiske betydningssammenhænge gestalter vores måde at opleve de mange sociale bevægelser og fragmenterede felter i oplevelsessamfundet. De skal sætte os i stand til at analysere, hvorledes iscenesættelsen af oplevelsessamfundet bidrager til organiseringen af den kollektive subjektivitet. Det er afgørende at forstå, hvorledes de utallige oplevelsestilbud besætter forventninger og forhåbninger og dermed bliver styrende i den givne livssituation.

Den symboliserede mangfoldighed er udtryk for en praksis, der ikke kun manifesterer sig i de tusindvis af tegn, der som meningsbærere transporterer sociale koder. Disse koder sætter sig også igennem som handlingsanvisninger i det enkelte menneskes subjektive struktur, både manifest på det bevidste plan og latent på det ubevidste plan. Gennem omgivelserne formidles oplevelsesmønstre, der som livsskitser og livsforventninger indlejres i vores fysiske og psykiske habitus. På den måde bliver kollektive iscenesættelser omdannet til inderliggjorte interaktionsfigurer, der er personlighedsdannende, og som hele tiden er i virksomhed ved siden af og bag ved den verbale forståelse. De kommer til syne i scener og træder frem i reaktioner, der nok mærkes, men ikke registreres fuldt bevidst.

Derfor må figurationssociologien inddrage socialisationsteorien og suppleres med oplevelsesanalyser, som peger frem mod en dynamisk processociologi, der er mere vidtrækkende end den, vi kender i dag. Et skridt på vejen mod en videnssociologisk centralteori. 
1. Gerhard Schulze, Die Erlebnisgesellschaft. Kultursoziologie der Gegenwart (Frankfurt a/M, 1993).

2. Johan Goudsblom, Soziologie auf der Waagschale, (Frankfurt a/M, 1979) (Sociology in Balance. A Critical Essay (Oxford, 1977).

3. Norbert Elias' omfattende samling af efterladte skrifter (Nachlaß) er arkiveret i Deutsches Literaturarchiv, Marbach am Neckar. Jeg har her fundet forskellige upublicerede skrifter til temaet Über das Gegenstandsgebiet der Soziologie. De her anførte overvejelser er uddrag fra Elias' Nachlass.

4. Alfred Lorenzer, Das Konzil der Buchhalter. Die Zerstörung der Sinnlichkeit. Ein Religionskritik (Frankfurt a/M, 1981).

5. Cours de philosophie positive er kommet i en række optryk. Den udgave, der i det følgende henvises til, er éd. Paris 1907.

6. Citeret efter Norbert Elias, Was ist Soziologie? (München, 1970) p. 5.

7. Ibid, p. 37.

8. Ibid, p. 41.

9. Goudsblom, op.cit., pp. 14-15.

10. Ibid., p. 15.

11. Johan Goudsblom har i den nævnte bog Soziologie auf der Waagschale givet en god indføring i og kritik af de fremherskende sociologiske teoridannelser. Se især kapitel 1, pp. 9-36.

12. Elias: Was ist Soziologie?, op.cit., p. 10.

13. Ibid., p. 9.

14. Ibid.

15. Ibid., p. 11.

16. Ibid. p. 12.

17. Goudsblom op.cit, pp. 143-44.

18. Ibid pp. 142, se endvidere pp. 142-50.

19. Elias 1970, op.cit., p. 140.

20. Begrebet Verflechtung er svært at oversætte, idet vi ikke har et ord med helt samme betydning på dansk. Det betyder på én gang sammenfletning, indfletning, viklen ind $i$, forvikling og sammenkædning.

21. Elias, op.cit., p. 140.

22. Ibid., p. 96.

23. Ibid., p. 76.

24. Norbert Elias og Eric Dunning har i forbindelse med deres sportssociologiske arbejder benyttet figurationsanalyser. Se f.eks. »Zur Dynamik von Sportgruppen, unter besondere Berücksichtigung von Fußballgruppen« I: Günther Lüschen (Hrsg.), Kleingruppenforschung und Gruppe im Sport (Kölner Zeitschrift für Soziologie und Sozialpsychologie Sonderheft 10) (Opladen, 1966), pp.
118-34. Se endvidere samme forfatters Quest for Excitement. Sport and Leisure in the Civilizing Process (Oxford, 1986).

25. Elias, op.cit., pp. 76-77.

26. Ibid., p. 79.

27. Ibid., p. 80.

28. Ibid., p. 81.

29. Ibid.

30. Ibid., pp. 82-83.

31. Ibid., pp. 84-85.

32. Ibid., p. 99.

33. Ibid., p. 85

34. Ibid., p. 87.

35. Norbert Elias, Engagement und Distanzierung. Arbeiten zur Wissenssoziologie I (Frankfurt a/M, 1983). Die Gesellschaft der Individuen (Frankfurt a/M, 1987). Über die Zeit. Arbeiten zur Wissenssoziologie II (Frankfurt a/M, 1984).

36. Elias 1970, op.cit., p. 88.

37. Ibid.

38. Ibid.

39. Ibid., p. 89.

40. Ibid., p. 90.

41. Ibid.

42. Ibid.

43. Ibid., p. 91.

44. Ibid.

45. Ibid., p. 92.

46. Ibid., p. 93.

47. Ibid., p. 93.

48. Ibid.

49. Ibid., p. 94.

50. Jeg tilslutter mig Elias’ påpegning af, at vores hverdagssprog er utilstrækkeligt til at optage og beskrive meget små og nuancerede forandringer i de sagforhold, man $\varnothing$ nsker at beskrive, idet man ofte kommer til at udtrykke nuancer for groft og bastant. Endvidere er gradbøjningen af adjektiver ofte for usmidig til at udtrykke dynamiske forskelle. Elias skriver:

»Endnu savnes på vort nuværende udviklingsstadie et sprogligt apparatur, som er tilpasset alle disse processers langsomme glidning. Det er et upræcist og foreløbigt hjælpemiddel, når man siger: »Menneskenes bundethed til deres driftsytringer blev større«, integrationen blev »tættere«, interdependensen »stærkere«, på samme måde som man ikke får føling med den historisk-samfundsmæssige virkelighed, når man siger: Dette er $»$ naturaløkonomi $\ll$, dette er »penge økonomi $\ll$, eller for at gentage den udtryksmåde, der blev valgt 
her: »Sektoren for pengeøkonomiske udvekslinger voksede«. Hvor meget »voksede« den, skridt for skridt? På hvilken måde er bindingerne »større «, integrationen »tættere«, interdependensen »stærkere «? Vores begreber er for udifferentierede; de lægger sig tæt op ad forestillingen om materielle substanser. Det drejer sig i forbindelse med alt dette ikke blot om gradvise forskydninger, om et »mere« eller »mindre«. Enhver »styrkelse « af bindingerne og interdependenserne er udtryk for, at menneskenes bindinger til hinanden, deres henvisthed til hinanden, deres indbyrdes afhængighed er blevet anderledes, kvalitativt anderledes. Det er dette, der menes, når man taler om forskelle mellem samfund. Og med det dynamiske netværk af afhængigheder, som menneskelivet er spundet ind i, antager menneskenes drifter og adfærdsformer også en anden skikkelse. Det er dette, der refereres til, når man taler om forskelle $\mathrm{i}$ den sjælelige husholdnings opbygning eller i adfærdsnormer. Da sådanne kvalitative forandringer, der trods alle bevægelser frem og tilbage udspiller sig over lange tidssstræk, er forandringer, der peger i samme retning, kontinuerlige og målrettede processer og ikke kun regelløs vekslen, er det ved sammenligning af de forskellige faser muligt og nærliggende at tale om forskellige grader. Dermed er ikke sagt, at den retning, disse processer bevæger sig i, er en bevagelse mod det bedre, et "fremskridt«, eller en bevagelse mod det dårligere, et »tilbageskridt«. Men der er heller ikke sagt, at det drejer sig om kvantitative forandringer. Her, som så ofte i historien, er der tale om strukturforandringer, der mest anskueligt, men måske også mest overfladisk lader sig begribe under de kvantitative ændringers synsvinkel.« Norbert Elias, Über den Prozeß der Zivilisation (Frankfurt a/M, 1977 (1939)), bd. 2, pp. 117 (m.u.).

For at kunne beherske et givet stof mere nuanceret kan vi bruge Elias' spillemodeller som hjælpemiddel til at løse op for vores sprogs begrænsninger som adækvat udtryksmiddel i forbindelse med beskrivelsen af procesforl $\varnothing \mathrm{b}$. Men skal modellerne udnyttes, må de anvendes som værktøj til at sætte sociologen bedre i stand til at foretage strukturanalyser, uden at sproget enten mystificerer eller giver en forkortet fremstilling af de reelle omstændigheder. Empirien skal organiseres og symboliseres, således at både procesforløb, afhængigheder og forviklingsstrukturer indgår i vore analyser.
51. Elias 1970, op.cit., p. 95.

52. Ibid.

53. Ibid., pp. 100-01.

54. Ibid., p. 102.

55. Ibid., p. 101.

56. Ibid., p. 81.

57. Ibid., p. 88.

58. Ibid., p. 144.

59. Problemstillingen omkring affektive bindinger samt begrebet valens og dets betydning i Elias' sociologi kræver en grundigere gennemgang, end det har været muligt i denne sammenhæng. Forklaringen må ses som vejledende for forståelsen af symbolerne i fig. 2. Se i øvrigt Was ist Soziologie?, pp. 146-74, samt artiklen $»$ Soziologie und Psychiatrie«I: Hans Ulrich Wehler (Hrsg.), Soziologie und Psychoanalyse (Stuttgart), pp. 11-41.

60. Se Elias 1977, op.cit. bd. 1, pp. 312-36.

61. Elias 1970, op.cit., p. 148.

62. Wehler (Hrsg.), op.cit., pp. 32-33.

63. Elias 1970, op.cit., p. 148.

64. Ibid., p. 136.

65. Ibid., p. 150.

66. Tanker Elias har ytret over for mig i april 1979 i Frankfurt.

67. Elias 1977, bd. 1, pp. 1-50.

68. Frankfurt a/M, 1989.

69. Norbert Elias, Die höfische Gesellschaft (Darmstadt, 1969).

70. Ibid., p. 28.

71. Norbert Elias, Die höfische Gesellschaft, op.cit. og Norbert Elias, John L. Scotson, Etablierte und Außenseiter (Frankfurt a/M, 1990 (engelsk udg. 1965)).

72. Elias 1970, op.cit., p. 27.

73. Goudsblom, op.cit., p. 16.

74. Elias 1977, bd. 2, p. 8.

75. Alfred Lorenzer, »Freud: Die Natürlichkeit des Menschen und die Sozialität der Natur « I: Psyche. Zeitschrift für Psychoanalyse und ihre Anwendung, vol. 42 (Stuttgart, 1988), p. 436-37 (m.u.),Lorenzer citerer fra Luciano Meccacci, Das einzigartige Gehirn (Frankfurt a/M, 1986), pp. 9.

76. Søren Nagbøl, »Idræt og Arkitektur - krop, sprog og socialisering « I: Idrattens Steder. Idratshistorisk Årbog 1997 (Odense, 1998), pp. 149-77.

77. Norbert Elias, The Symbol Theory (London 1991).

78. Søren Nagbøl 1998, op.cit., p. 149. 